\title{
Penerapan Layanan email Murah pada Extreme Environment berbasis Prołocol Delay Tolerant Network (DTN)
}

\section{LAPORAN PENELITIAN PEMULA 2017}

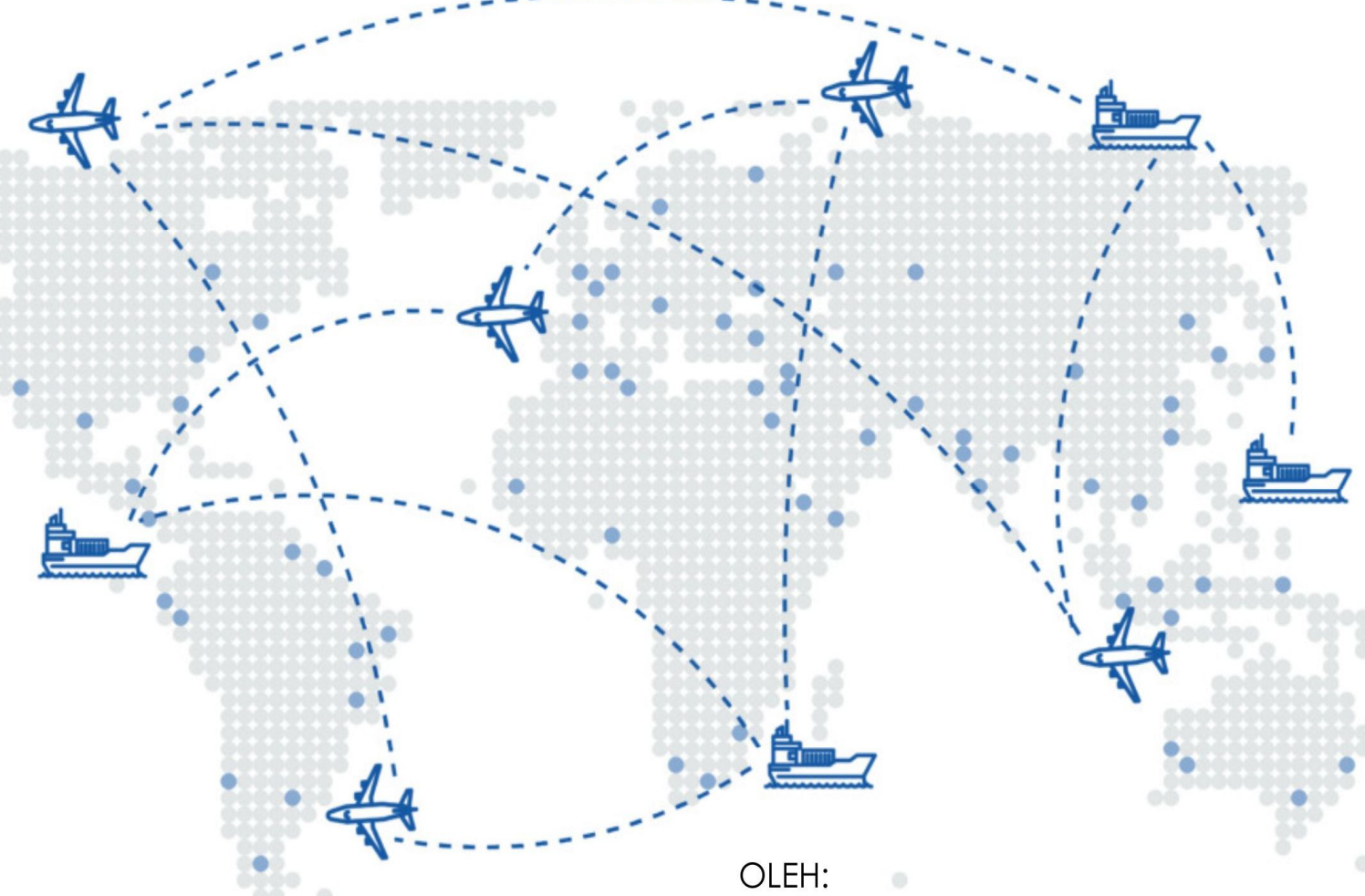

OKTAF BRILLIAN KHARISMA, ST.,MT

\section{J价鸩 LEMBAGA PENELITIAN DAN PENGABDIAN MASYARAKAT UIN SULTAN SYARIF KASIM PEKANBARU RIAU}




\section{DAFTAR ISI}

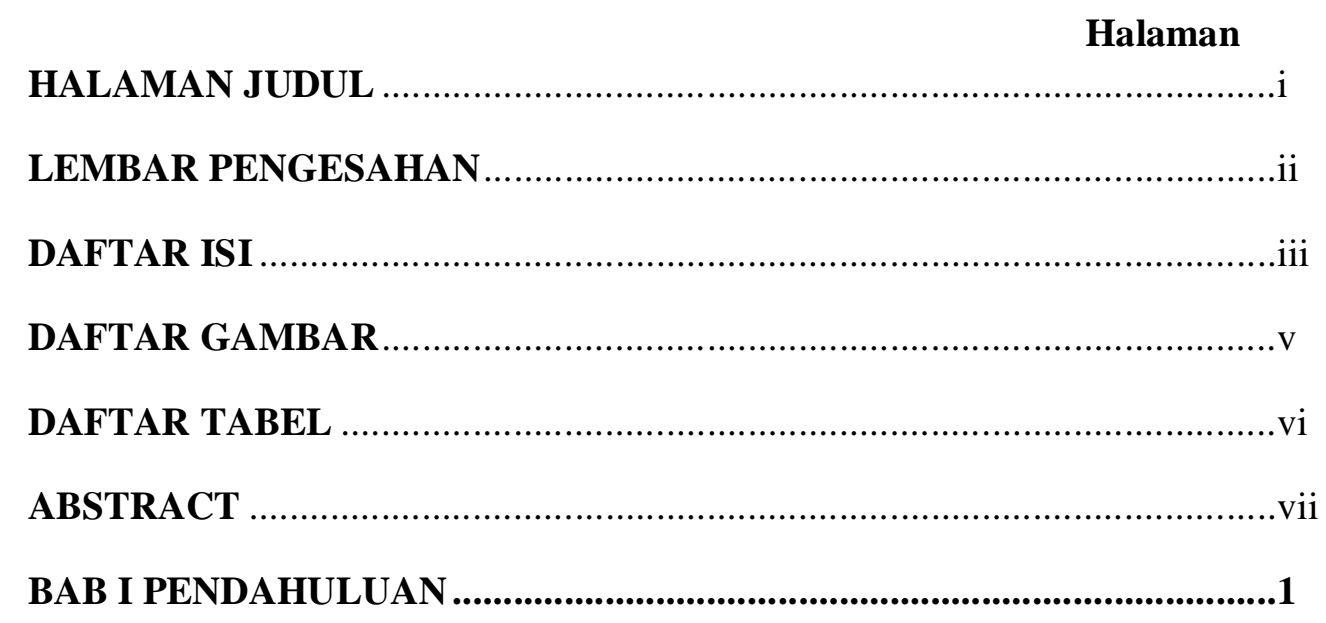

1.1 LatarBelakang ................................................................. 1

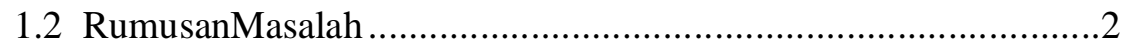

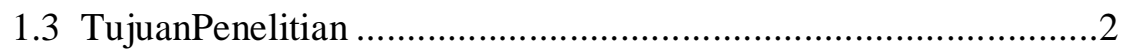

1.4 ManfaatPenelitian ............................................................... 3

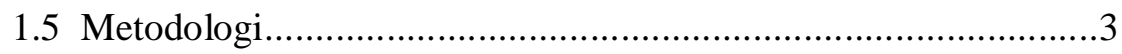

1.6 Batasan Masalah ..........................................................4

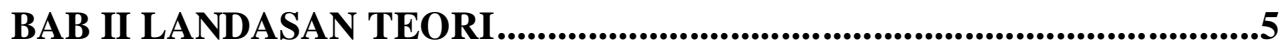

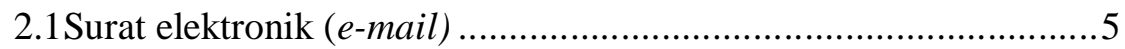

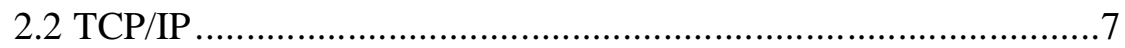

2.3 Delay Tolerant Network $(D T N)$............................................... 11

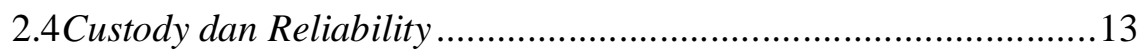

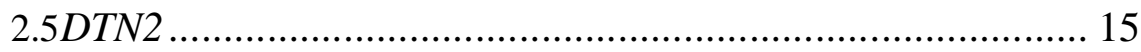

BABIII METODOLOGI PENELITIAN .......................................................16

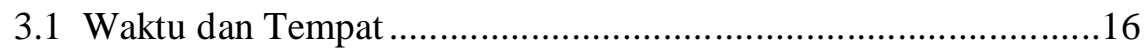

3.2 Model JaringandanSistemLayanan Email ................................16

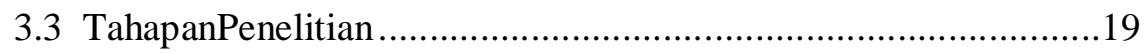

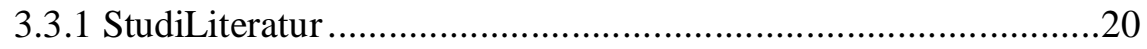




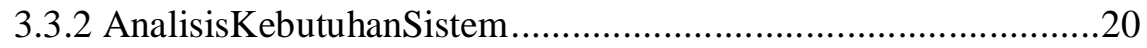

3.3.2.1 KebutuhanSistemLayanan email ..................................20

3.3.2.2 KebutuhanSistemJaringan..........................................22

3.3.3 Perancangan Hardware ........................................................24

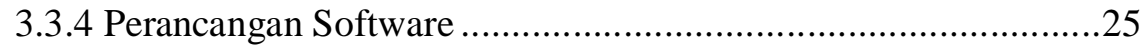

3.3.4.1 Instalasidankonfigurasi DTN2 …..............................25

3.3.4.2 Program KirimdanTerima email (Server email) ..............29

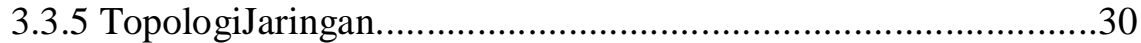

BAB IV HASIL DAN PEMBAHASAN ........................................................31

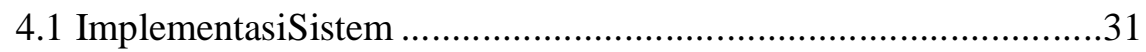

4.1.1 ImplementasiIntegrasiAplikasi DTN2 dengan API Python ........31

4.1.2 Pengujian Program Aplikasi Server Email ...............................32

4.1.3 PengujianAplikasiSquirrelmail ...............................................33

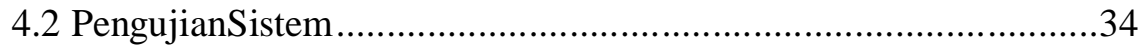

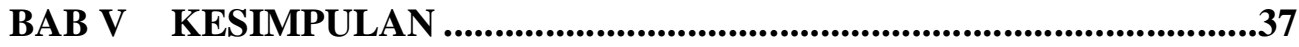

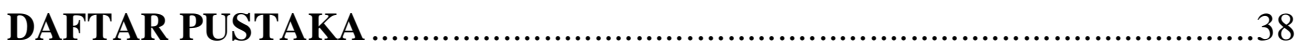

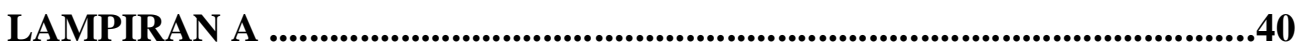

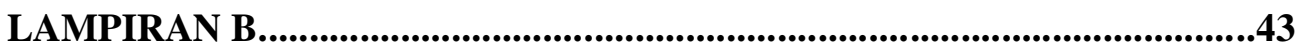

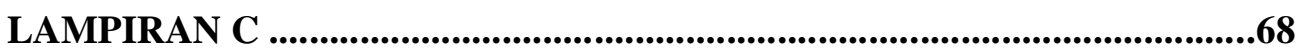




\section{DAFTAR GAMBAR}

Gambar 2.1 Proses kerjapengirimane-mail ................................................. 5

Gambar 2.2 Lapisan - lapisanpada TCP/IP ........................................... 8

Gambar 2.3 Routing data darisumberketujuan ........................................ 10

Gambar 2.4Percakapanantarakirimdanterimapada proses transfer data ............ 11

Gambar 2.5 Ilustrasimekanismestore-and-forwardpada DTN........................ 12

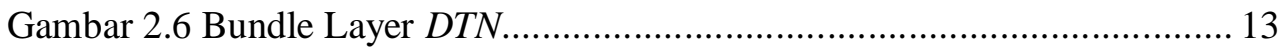

Gambar 2.7 Strukturdari DTN gateway denganbeberapaconvergence layer...... 14

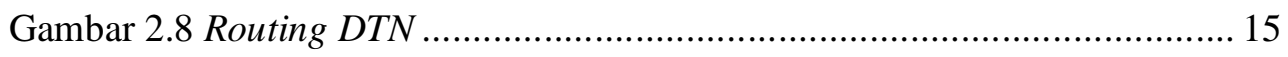

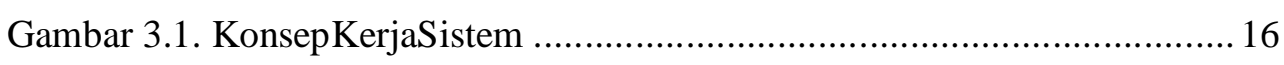

Gambar 3.2. TahapanPenelitian......................................................... 19

Gambar 3.3 Elemenpenyusunlayanan email menggunakanjaringan DTN .........22

Gambar 3.4 ElemenJaringan DTN Layanan Email ....................................... 23

Gambar 3.5 KonfigurasiJaringan DTN................................................. 24

Gambar 3.6 Flowchart Program KirimdanTerima Email ................................. 30

Gambar 3.7 KonsepTopologidenganMetodeFlooding .................................. 30

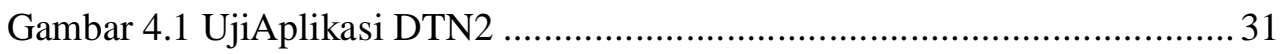

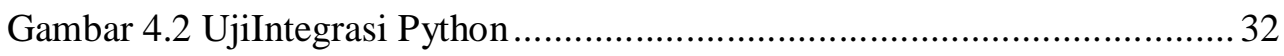

Gambar 4.3 TampilanAplikasiServer Email ................................................. 32

Gambar 4.4 Tampilan Email yang ter-Bundle ........................................... 33

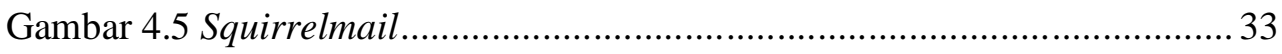

Gambar 4.6 Tampilan email yang diterimaoleh user melaluijaringan DTN....... 34

Gambar 4.7 Pengujiandenganmetodeflooding ............................................ 34

Gambar 4.8 Grafikukuran email terhadapwaktu ......................................... 35 


\section{DAFTAR TABEL}

Tabel 3.1 Konfigurasi IP tiap node jaringan DTN ..................................... 25

Tabel 4.1 Pengujian Bundle Email ................................................................. 35 


\title{
ABSTRACT \\ PenerapanLayanan Email MurahpadaExtreme Environment berbasisProtocol Delay Tolerant Network (DTN)
}

Oleh:

\section{Oktaf Brillian Kharisma, ST., MT}

\begin{abstract}
Abstrak- Kondisi geografis Indonesia yang terdiri dari lembah, gunung serta berkepulauan ternyata menjadi penyebab tidak meratanya penyebaran teknologi internet. Sehingga banyak pengguna atau masyarakat Indonesia yang belum dapat menikmati layanan internet salah satunya dalam pengiriman e-mail. Delay Tolerant Network (DTN) merupakan suatu protocol jaringan yang memungkinkan jaringan komunikasi dibangun di suatu lingkungan ekstrim yang memiliki karakteristik delay yang panjang, tingkat loss yang tinggi, serta tingkat konektivitas yang rendah. Dengan menggunakan DTN, layanan internet dapat diterapkan dan disajikan dengan mufal dqngan mentan kendaran yang

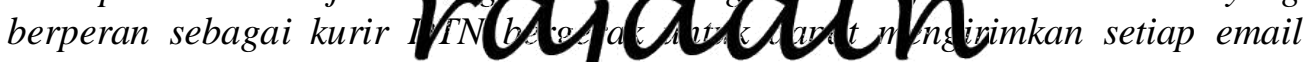
ketujuan. Kurir akan bergerak kel iwasan terpencil yang membutuhkan akses jaringan dan mengumpulkan data-data email secara digital selanjutnya kurir akan bergerak ketempat yang memiliki akses internet untuk memproses setiap permintaan tersebut. Dari hasil pengujian pada penelitian ini, hampir setiap email masuk dapat ter-bundle dan terkirim dengan sempurna ketujuan.
\end{abstract}

Keyword :DTN, bundle, email-bundle. 


\section{BAB I \\ PENDAHULUAN}

\subsection{Latar Belakang}

Kebutuhan akan komunikasi internet untuk saat ini telah terintegrasi dalam kehidupan sehari-hari dan sudah menjadi kebutuhan primer untuk setiap korporasi, institusi pemerintahan, sekolah, dan juga perguruan tinggi.Sehingga,kemunculannya berdampak pada pola ataupun kebiasaan masyarakatyang semula menggunakan media konvensional beralih ke media digital yang lebih cepat dan akurat, semisal dalam proses pengiriman surat yang saat ini sudah beralih ke elektronik mail (e-mail).

Namun, melihat keadaan geografis Indonesia yang begitu "Ekstrim", yaitu berupa daratan tinggi, dataran rendah, pegunungan dan pantai ternyata menyebabkan masalah DigitalDivide, yang berarti masih banyak kawasan di Indonesia belum terjangkau oleh penyelenggara Internet, Internet Service Provider (ISP). Sehingga, banyak pengguna yang belum dapat menikmati layanan internet salah satunya dalam pengiriman e-mail. Selain biaya instalasi dan biaya berlangganan layanan internet begitu mahal. Hal ini juga menjadi kendala dalam membangun infrastruktur internet di area tersebut. Bahkan Menteri Komunikasi dan Informasi memberikan data statistik bahwa pada bulan Juni 2009, 31 ribu desa di Indonesia masih belum terjangkau Internet. Sedangkan, di tahun 2016 berdasarkan data dari sumber yang sama Indonesia yang terdiri dari 17.504 pulau hanya sekitar 2\% saja yang tercatat mendapatkan layanan internet [1][2]. selain itu masih banyak sekali blank spot (area-area yang tidak terjangkau Internet) meskipun sudah terjangkau Internet.

Sebuah teknologi tepat guna seperti Delay Tolerant Network (DTN)yang merupakan suatu arsitektur dan protokol jaringan yang dirancang untuk mampu menyajikan komunikasi di suatu lingkungan yang memiliki karakteristik waktu tunda yang bervariasi atau panjang, error rate yang tinggi, laju data yang tidak 
simetris dan hubungan yang hanya sebentar-sebentar (on-off-on-off) akan cocok digunakan dalam lingkungan ekstrim seperti di-Indonesia ini.

Mengacu pada permasalahan tersebut, melalui penelitian ini akan di sajikan sebuah solusi dengan mengimplementasikan sistem layanan aplikasi e-mailmurah dan terjangkau untuk kawasan ekstrim dan terpencil serta kawasan yang tidak terjangkau internet sekalipun berbasiskan protokol Delay Tolerant Network (DTNuntuk harapan nantinya akan menghasilkan future internet yang dapat digunakan pada segala kondisi dan dapat menekan biaya layanannya.

\subsection{Rumusan Masalah}

Berdasarkan pemaparan latar belakang diatas dapat dirumuskan, yaitu Bagaimana membangun jaringan ber-delay untuk kepentingan pengiriman email pada kawasan yang tidak terjangkau internet.

\subsection{Tujuan Penelitian}

1. Mengenalkan teknologi jaringan internet berbasis Delay Tolerant Network (DTN);

2. Membangun sebuah layanan e-mail yang murah dan terjangkau untuk kesejahteraan masyarakat di daerah terpencil ;

3. Menghasilkan layananinternet yang dapat digunakan pada segala kondisi termasuk pada desa dan daerah terpencil;

4. Meningkatkan penyebaran potensi sumber daya alam yang dimiliki daerah terpencil melalui layanan internet berbasis Delay Tolerant Network (DTN). 


\subsection{Manfaat Penelitian}

Adapun manfaat penilitan ini adalah sebagai berikut :

1. Mengenalkan teknologi jaringan internet berbasis Delay Tolerant Network (DTN);

2. Meningkatkan penyebaran potensi sumber daya alam yang dimiliki kawasan terpencil melalui layanan internet berbasis Delay Tolerant Network (DTN).

\subsection{Metodologi}

Adapun metodologi yang digunakan dalam tugas ini adalah sebagai berikut :

\section{Studi Literatur}

Pada tahap ini akan dilakukan studi literatur tentang TCP/IP, DTN,DTN2, topologi transmisi data, macam-macam algoritma routing, instruksi-instruksi linux yang dibutuhkan, serta interfacependukungnya.

\section{Pengumpulan Data}

Data yang diambil adalahkemampuan server DTN dalam menangani email yang masuk.

\section{Perancangan Sistem}

Tahapan perancangan sistem atau desain system secarakeseluruhan yang akan dibangun.

\section{Pembuatan Sistem}

Tahapan yang dilakukan untuk pembuatan sistem ini adalah pembuatan kemampuan utama sistem ini. Proses-proses itu dibuat secara bertahap sesuai dengan urutan yang disebut di kerangka kerja. Hal pertama yang dilakukan adalah melakukan proses koneksi antar node. Selanjutnya diikuti proses transfer email yang dimaksud. 


\section{Pengujian dan Analisa}

Pengujian dan analisa dimaksudkan untuk mengetahuisistem yang dibuat dalam penelitian ini dapat berfungsi sesuai dengan yang diharapkan serta menganalisa hasil tiap tahapan proses dan hasil secara keseluruhan. Hasil yang dianalisa adalahreliability system yang dibangun.

\section{Pembuatan Laporan}

Membuat dokumentasi berupa laporan yang berisi tentang dasar teori, hasil tugas, serta hasil analisa dari semua tahapan proses di atas.

\subsection{Batasan Masalah}

Batasan masalah pada penelitian yang akan dilaksanakan ini antara lain :

1. Jaringan menggunakan protokol DTN dengan memanfaatkan aplikasi DTN2;

2. Pengiriman email menggunakan aplikasi squirrelmail;

3. Hanya di fokuskan pada penerapan layanan email bebrasis delay tolerant network;

4. Data yang diujikan merupakan data e-mail yang dikirimkan oleh user dari jaringan internetluar ke alamat desa.

BAB II 


\section{TINJAUAN PUSTAKA}

\subsection{Surat Elektronik (E-mail)}

Email adalah singkatan dari "Electronic Mail" yaitu sarana kirim mengirim surat/pesan secara elektronik yaitu melalui jalur internet. Surat tersebut dapat berupa teks saja, maupun gabungan dengan gambar. Dengan surat biasa umumnya pengirim perlu membayar per pengiriman (dengan membeli perangko) tetapi surat elektronikumumnya biaya yang dikeluarkan adalah biaya untuk membayar sambungan /akses internet.[3]

Surat elektronik sudah mulai dipakai pada tahun 1960-an. Pada saat itu Internet belum terbentuk, yang ada hanyalah kumpulan 'mainframe' yang terbentuk sebagai jaringan. Mulai tahun 1980-an, surat elektronik sudah bisa dinikmati oleh khalayak umum. Sekarang ini banyak perusahaan pos di berbagai negara menurun penghasilannya disebabkan masyarakat sudah tidak memakai jasa pos lagi.[4]

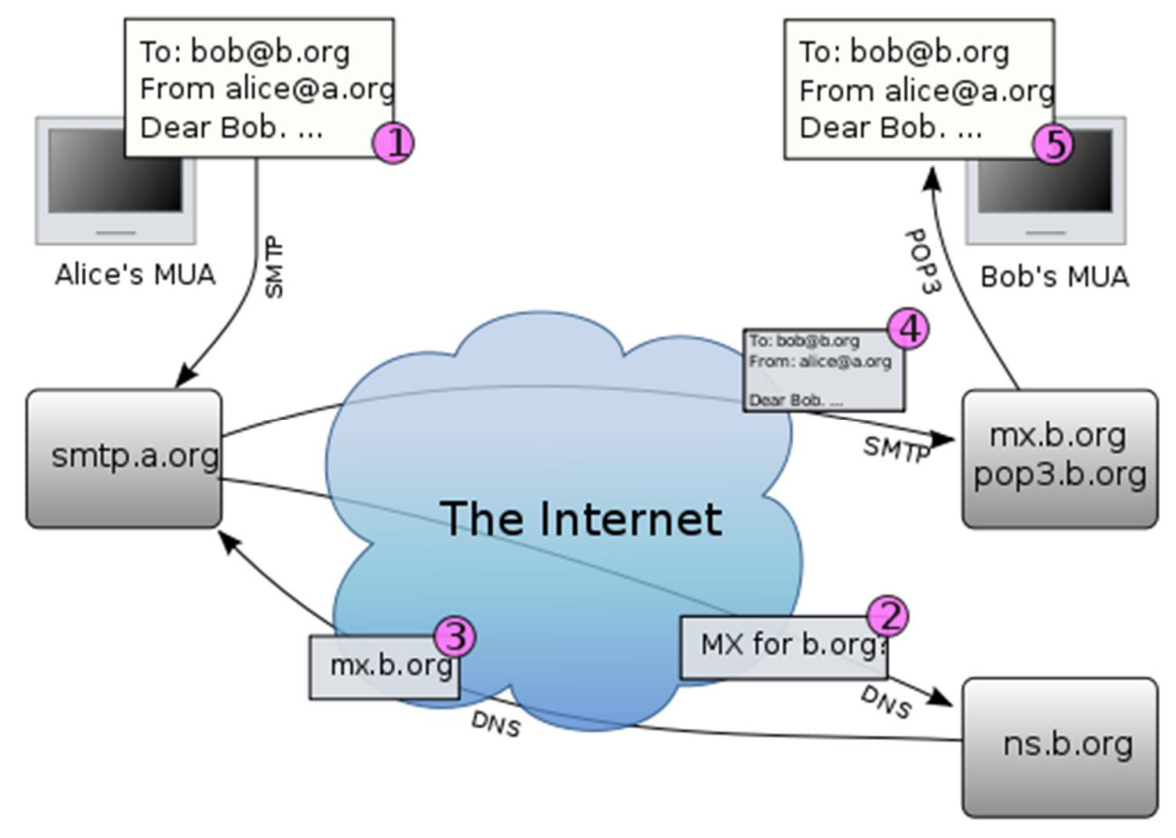

Gambar 2.1 Proses kerja pengiriman $e$-mail[4] 
Konsep e-mail pertama kali dikemukakan oleh Ray Tomlinson pada akhir tahun 1971. Ray Tomlinson pada saat itu bekerja untuk Bolt Beranek and Newman "BBN" milik lembaga pertahanan Amerika. Pada awalnya" Ray bereksperimen dengan program komputer yang bernama SNDMSG yang pada saat itu digunakan untuk meninggalkan pesan pada komputer, sehingga orang yang memakai komputer dapat membaca pesan yang ditinggalkan oleh pemakai komputer "saat itu normal ketika banyak orang menggunakan komputer yang sama secara bergantian".

Eksperimen Ray kemudian dilanjutkan dengan menghubungkan SNDMSG melalui file protocol yang bernama CYPNET sehingga program SNDMSG dapat mengirimkan pesan ke komputer lain" namun masih berada dalam satu jaringan ARPAnet. Eksperimen tersebut berhasil dan Itulah awal terciptanya Surat Elektronik (e-mail).

Pesan surat elektronik (e-mail) pertama kali yang dikirim oleh Ray pada 1971 merupakan surat elektronik (e-mail) pertama di dunia. Isi Pesan berupa "kata kata tes" sepenuhnya dilupakan, Kemungkinan pesan pertama yang dikirimkannya adalah QWERTYUIOP atau huruf serupa," kata Ray dalam akun Flickr miliknya. Pada tahun 1972, Ray mengenalkan lambang @ "Indonesia dibaca ET" sebagai identitas email untuk memisahkan antara Identitas pengguna dengan domain. @ "bahasa inggris ditulis AT" artinya adalah "kepada".[4]

Seperti yang terlihat pada Gambar 2.1. Proses kerja untuk mengirim e-mailmelalui 5 poin yaitu diperlukan suatu program mail-client. Surat elektronik (e-mail) yang terkirim akan melalui beberapa poin sebelum sampai di tujuan. Mulai dari surat elektronik dikirim $\rightarrow$ Internet $\rightarrow$ POP3 server penyedia surel penerima $\rightarrow$ mail client (di komputer si penerima) $\rightarrow$ surat elektronik dibaca si penerima.[4] 


\subsection{Transport Control protocol/Internet Protocol (TCP/IP)}

Kesuksesan internet sebagai sarana komunikasi antara jaringan di seluruh dunia disebabkan karena semua perangkat komunikasi yang terlibat dalam internet menggunakan sebuah protokol komunikasi yang sama, yaitu TCP/IP. Semua perangkat dalam subnet-subnet internet menggunakan TCP/IP untuk mengirim, meneruskan dan menerima data, serta memastikan kehandalan dalam pengiriman pesan.

Koneksi pada internet masih bertumpu pada jalur kabel, termasuk jalur kabel telepon meskipun jalur nirkabel seperti jalur radio jarak pendek dan komunikasi satelit mulai muncul. Jalur ini terhubung secara terus menerus dari end-to-enddan memiliki tingkat waktu tunda perambatan yang rendah antara sumber dan tujuan. Koneksi internet juga memiliki tingkat kesalahan data yang rendah dan laju data kedua arah yang relatif simetris.

Jika di lihat dari Sumber dan tujuan pada pengiriman data di internet, setidaknya memiliki lima lapisan dengan masing-masing protokolnya sendiri. Antara lain, yaitu :

- Lapisan aplikasi, menerima atau menghasilkan data dari beragam layanan yang diberikan.

- Lapisan transport, berfungsi memecah data dari lapisan aplikasi ketika pengiriman data dan menyusun ulang di tujuan akhir. Lapisan ini dilengkapi dengan fasilitas koreksi kesalahan. Lapisan transport beroperasi end-to-endsehingga lapisan transporthanya terdapat pada sumber ke tujuan,

- Lapisan network, berfungsi mengantarkan data dari sumber ke tujuan melalui beberapa node.

- Lapisan datalink, berfungsi sebagai perantara antara lapisan networkdengan lapisan physical. Lapisan datalinkmenentukan bagaimana data dikirimkan, menyesuaikan dengan lapisan physicalyang digunakan. 
Contoh lapisan datalink yang umum digunakan antara lain Ethernet untuk Local-Area Networks(LAN) dan Point-to-Point Protocol(PPP) untuk dialup modem.

- Lapisan physical, perangkat pengirim data dalam bentuk aliran bit.Contoh lapisan physicalyang umum digunakan antara lain kabel UTP, kabel telepon, kabel coaxial dan 802.11 Wirelesss Local Area Network(WLAN).

Posisi lapisan-lapisan pada Internet ditunjukkan dalam Gambar 2.2 di bawah ini:

\section{Application Layer}

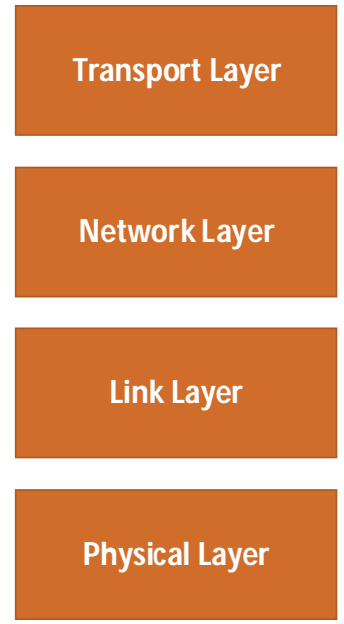

Gambar 2.2 Lapisan - lapisan pada TCP/IP

Komunikasi pada internet berbasis packet switching. Packetadalah pecahan dari sebuah blok data. Masing-masing paket yang berasal dari sebuah blok data berjalan secara independen dari sumber ke tujuan melewati beberapa nodeyang disebut router. Masing-masing paket dapat menempuh rute yang berbeda ketika berjalan dari sumber ke tujuan. Paket berisi data dari aplikasi dan sebuah pengenal atau header. Headerberisi tujuan akhir dari paket dan informasi yang menentukan bagaimana paket akan dikirim dari satu router ke router yang lain. Paket-paket 
dapat sampai di tujuan secara tidak urut, tetapi mekanisme pada lapisan transportmenyusun ulang paket-paket tersebut sesuai urutan ketika pengiriman.

Penggunaan internet bergantung pada beberapa asumsi yang harus dipenuhi, yakni:

- Continous, biderectionalend-to-end path, yakni tersedianya jalur yang selalu ada antara sumber dan tujuan untuk mendukung interaksi endto-end.

- Short round-trips, yakni waktu tunda yang kecil dan relatif konsistenketika proses pengiriman data, serta ketika pengirimanacknowledgementyang menyatakan bahwa data telah diterima denganbaik di tujuan.

- Laju data simetris. Laju data yang relatif sama di kedua arah antara sumber dan tujuan.

- Tingkat kesalahan rendah. Tingkat kesalahan dan kehilangan data yang relatif rendah pada setiap nodedalam jaringan.

Router berfungsi untuk meneruskan data. Router hanya mengimplementasikan tiga lapisan terbawah, yaitu lapisan physical, data link, dan network. Masingmasing router dapat menggunakan teknologi yang berbeda-beda pada lapisan datalinkdan physical, tetapi menggunakan protokol networkyang sama yaitu Internet Protocol(IP) dan protokol transportyang sama yaitu Transmission Control Protocol(TCP). IP berjalan pada semua nodedalam jaringan sedangkan TCP hanya berjalan pada sumber dan tujuan akhir. TCP/IP menyediakan pilihan jalur routing, pemilihan jalur, resolusi nama, dan layanan perbaikan kesalahan. Proses routingdata dari sumber ke tujuan ditunjukkan pada Gambar 2.3 dibawah ini : 


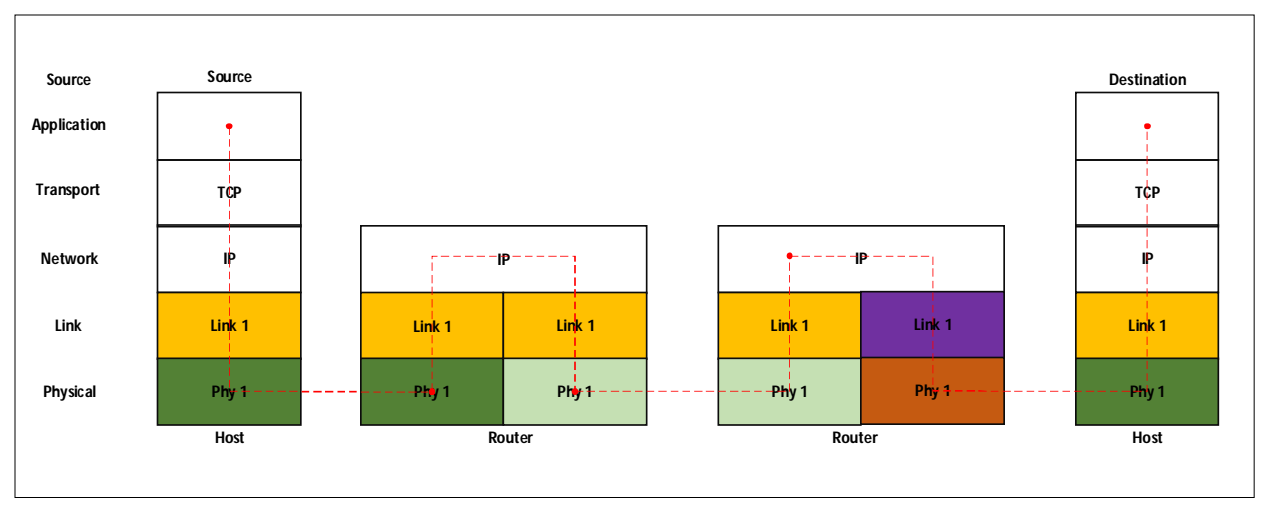

Gambar 2.3 Routing data dari sumber ke tujuan

TCP/IP disebut protokol yang interaktif karena membutuhkan percakapan ketika melakukan proses transfer data. Transfer data diawali oleh sinyal SYN dari sumber yang menandai dimulainya percakaan TCP. Sinyal SYN tersebut dibalas oleh tujuan dengan mengirimkan sinyal yang menyatakan sinyal SYN telah diterima (SYN ACK). Sinyal SYN ACK dibalas oleh sumber dengan mengirimkan sinyal ACK. Percakapan awal ini disebut jabat tangan tiga arah (three way handshake).

Setelah three way handshakeselesai dilakukan, barulah proses transfer data dapat dilakukan. Setiap segmen yang dikirim oleh pengirim selalu dibalas dengan sinyal ACK oleh penerima. Sinyal ACK menandakan bahwa segmen telah diterima dengan baik oleh penerima. Apabila pengirim tidak menerima sinyal ACK, maka dilakukan transmisi ulang oleh pengirim.

Setelah pengirim selesai mengirim data, sinyal FIN dikirimkan sebagai tanda untuk mengakhiri proses transfer data. Sinyal FIN dari pengirim dibalas oleh sinyal ACK dari penerima, disertai sinyal FIN dari penerima yang menandakan bahwa semua paket telah diterima dengan baik oleh penerima. Percakapan diakhiri dengan sinyal ACK dari pengirim. Ilustrasi percakapan antara pengirim dan penerima dalam proses transfer data pada TCP/IP ditunjukkan dalam Gambar 2.4 di bawah ini: 


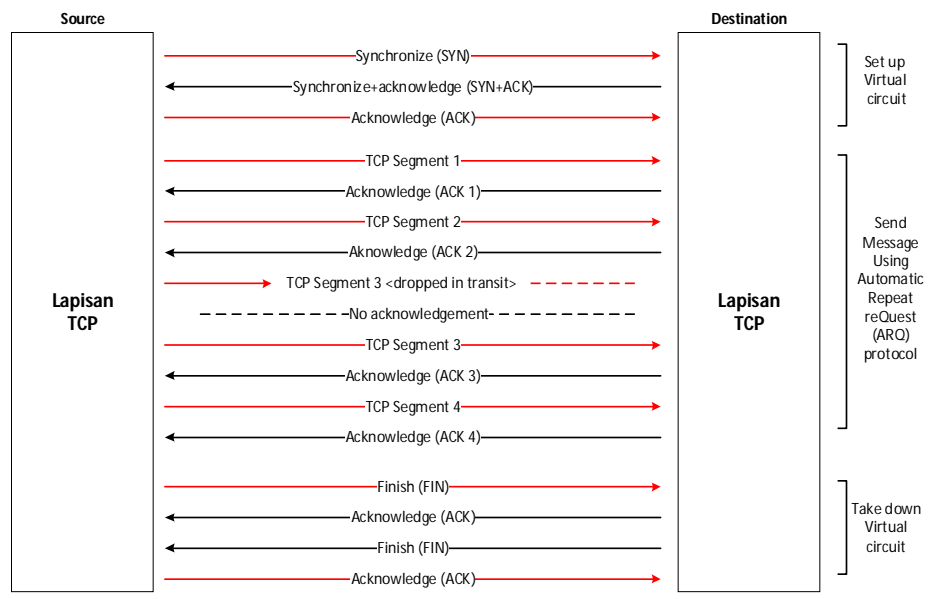

Gambar 2.4 Percakapan antara pengirim dan penerima pada proses transfer data

Performa jaringan TCP/IP ditentukan oleh beberapa faktor, antara lain waktu tunda dan throughput. Waktu tunda adalah waktu yang diperlukan oleh sebuah pesan (data) untuk sampai ke tujuan dengan utuh. Waktu tunda diukur sejak bit pertama dikirim oleh sumber hingga bit terakhir diterima oleh tujuan. Waktu tunda terdiri atas empat komponen, yaitu waktu perambatan, waktu transmisi, waktu pemrosesan dan waktu antrian. Total waktu tunda merupakan penjumlahan empat komponen tersebut.

Throughputadalah kemampuan maksimal jaringan untuk mengirim data. Satuan throughputadalah bit per detik. Throughputberbeda dengan lebar pita (bandwidth) meskipun memiliki satuan yang sama. Sebuah jaringan dpat memiliki bandwidthX per detik, tetapi hanya memiliki throughput $\mathrm{Y}$ bit per detik dimana $\mathrm{Y}$ kurang dari $\mathrm{X}$. Dengan kata lain, bandwidthadalah potensi kemampuan sebuah jaringan sedangkan throughput adalah kemampuan jaringan yang sebenarnya.

\subsection{Delay Tolerant Network (DTN)}

Delay Tolerant Network (DTN) merupakan suatuarsitektur dan protokol jaringan yang memungkinkanjaringan komunikasi dibangun di suatu lingkungan yangmemiliki karakteristik delay yang panjang, tingkat lossyang tinggi, dan tingkat konektivitas yang rendah dengancara menerapkan suatu metoda yang dinamakan store andforward packet switching.[5][6][7] 
Berikut ini adalah beberapa asumsi yang terdapat pada arsitektur DTN :

- Menggunakan variable length message (tidak terbatas pada ukuran paket) sebagai abstraksi komunikasi untuk membantu meningkatkan skemampuan jaringan dalam hal membuat penjadwalan yang baik atau pemilihan path apabila dirasa memungkinkan.

- Menggunakan sintaks penamaan yang mendukung berbagai macam penamaan dan pengalamatan untuk meningkatkan operabilitas.

- Menggunakan penyimpanan dimana jaringan mendukung operasi store and forward pada multiplepath dan secara potensial memiliki rentang waktu yang lebih panjang (contohnya untuk mendukung berbagai operasi di dalam lingkungan yang banyak terdapat atau tidak terdapat end-to-end path) serta tidak terlalu mementingkan end-to-end reliability.

- Menyediakan mekanisme keamanan untuk melindungi infrastruktur dari penggunaan yang tidak sah dengan cara menghilangkan traffic secepat mungkin.

Metoda store and forward merupakan metode lamaserupa dengan yang digunakan pada jaringan pos.Dengan metode store and forward, keseluruhan pesanatau data dipindahkan terlebih dahulu dari satu node kenode yang lain hingga akhirnya sampai ke tujuan.Ilustrasi mekanisme store and forwardditunjukkan dalamGambar 2.5.[5][8]

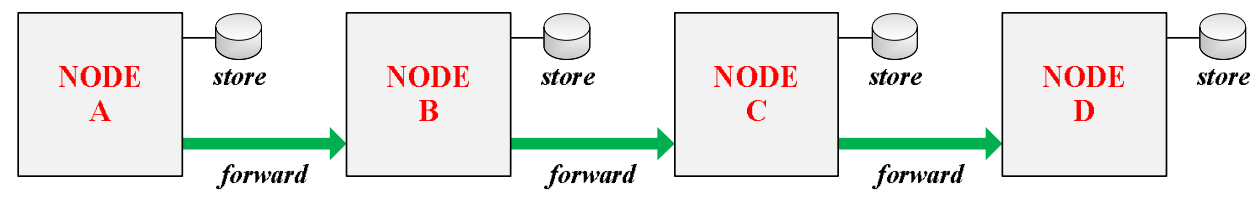

Gambar 2.5 Ilustrasi mekanisme store-and-forward pada DTN.

Sebuah node harus memiliki suatu media penyimpanan (seperti hard disk) yang dapat menyimpankeseluruhan data. Data dapat berada pada sebuah nodedalam jangka waktu yang lama, berbeda dengan packetpada internet yang hanya akan tersimpan dalam sebuahrouter dalam hitungan milidetik atau mikrodetik. 
Sebuahrouter DTN membutuhkan tempat penyimpan karenabeberapa alasan berikut:

- Jalur yang menghubungkan sebuah node dengan node yang lain mungkin tidak tersedia dalam waktu yanglama.

- Komunikasi mungkin tidak dapat berlangsung secarasimetris, artinya, kecepatan sebuah node dalammengirim dan menerima data mungkin saja tidaksama.

DTN mengimplementasikan metode store andforward message switching dengan menggunakan sebuahlayer baru, yaitu bundle layer. Bundle layer menyimpan dan meneruskan keseluruhan bundle (atau sebuah fragmen saja) antara node-node yang berkomunikasidengan DTN. Posisi bundle layer ditunjukkan dalam Gambar 2.6.[9][10]

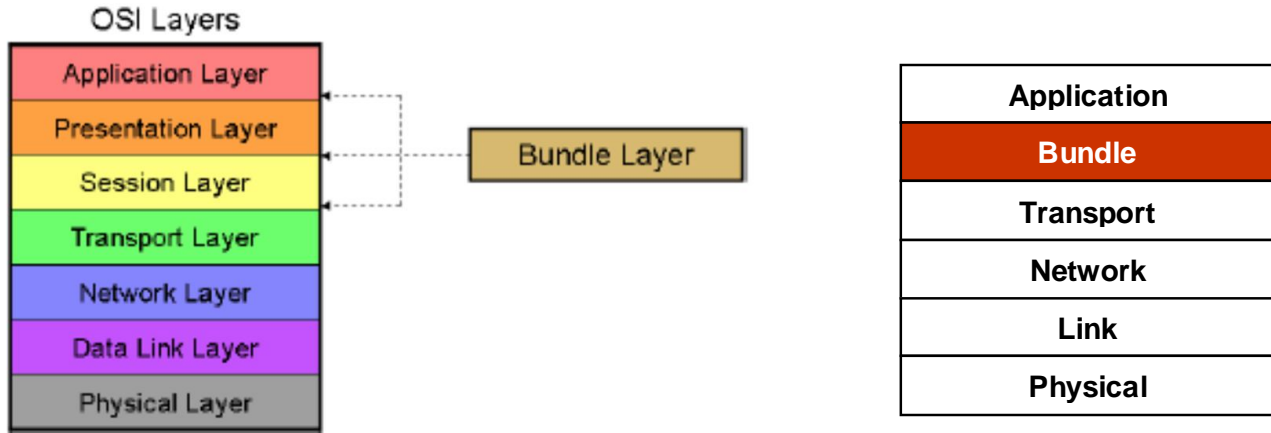

Gambar 2.6 Bundle Layer DTN[11]

\subsection{Custody Transfer danReliability}

Arsitektur DTN mencakup dua tipe yang berbedadari node-node routing pesan yaitu : persistent (P) dannon-persistent (NP). Node $\mathrm{P}$ diasumsikan mampumenampung sejumlah penyimpanan persistent message,yang tidak bisa dilakukan oleh node NP. Kecuali jikakedua node tersebut tidak mampu antau tidak maumenyimpan pesan tertentu, node $\mathrm{P}$ umumnya akanberpartisispasi dalam custody transfer denganmenggunakan protokol-protokol yang sesuai dari suatuwilayah tersebut. Custody Transfer mengacu kepadapengakuan pengiriman suatu pesan dari satu hop DTNke hop yang lain terkait dengan tanggung 
jawabpengiriman yang handal. Custody Transfer serupadengan memberikan tanggung jawab untuk memberikansurat pos kepada seseorang atau jasa yang menjanjikan(atau kontrak) dan sebagainya.Konsep custody transfer merupakan dasar dariarsitektur yang digunakan untuk memerangi tingkatkerugian yang berpotensi tinggi dan untuk meringankankemungkinan node akhir yang miskin sumber daya daritanggung jawab yang berkaitan dengan pemeliharaankeadaaan koneksi end-to-end. Secara khusus, biasanyaend-node tidak perlu menyimpan salinan data yangtelah secara custodial ditransfer ke hop berikutnya padaDTN. Untuk node yang tetap bersikeras untukmelakukan akcnowledgement end-to-end, "konfirmasipengiriman" bisa diminta secara opsional, meskipun dalam bagaimana menanggapi situasi ini diserahkankepada aplikasi yang meminta.

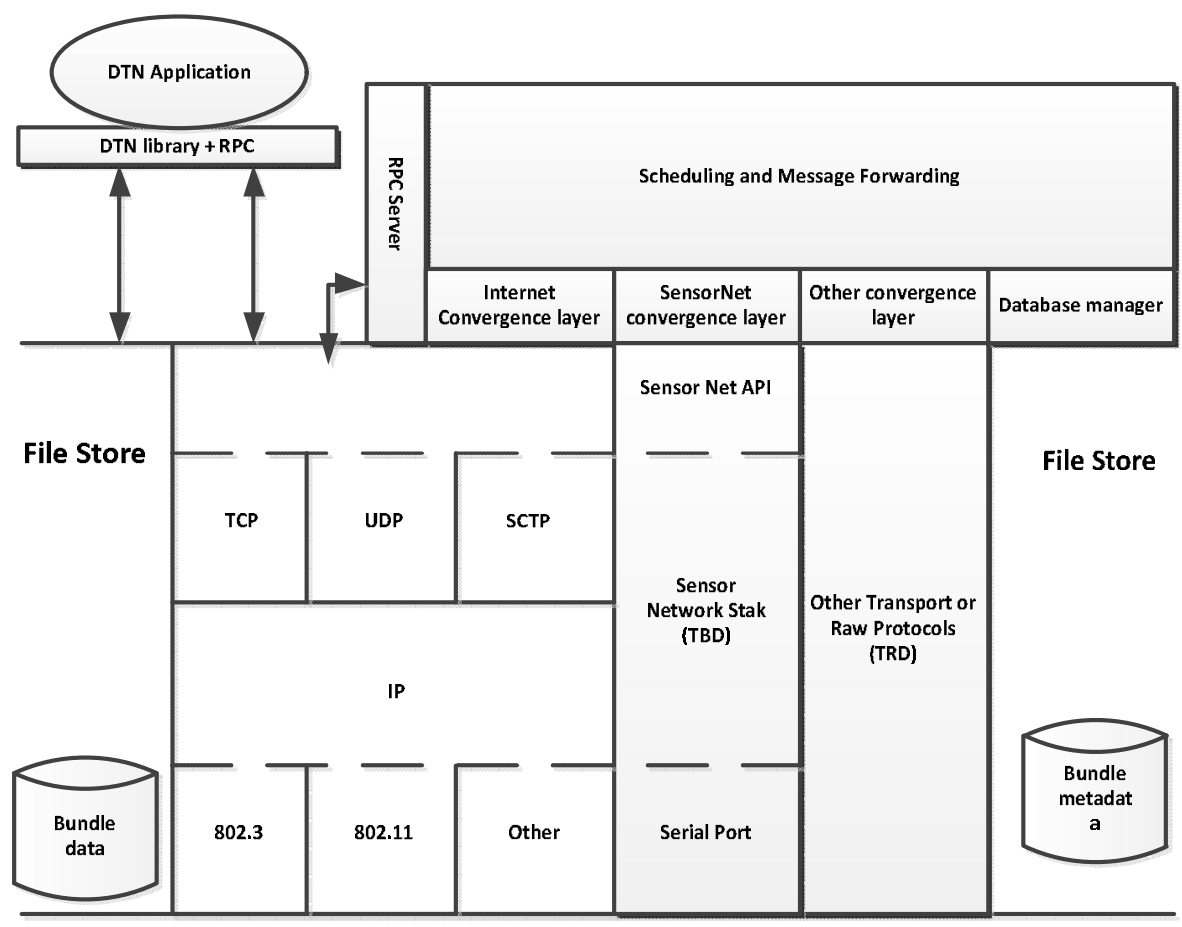

Gambar 2.7 Struktur dari DTN gateway denganbeberapa convergence layer, satu per protocol stack,menyediakan antarmuka umum untukpenjadwalan/pengiriman pesan.[7] 


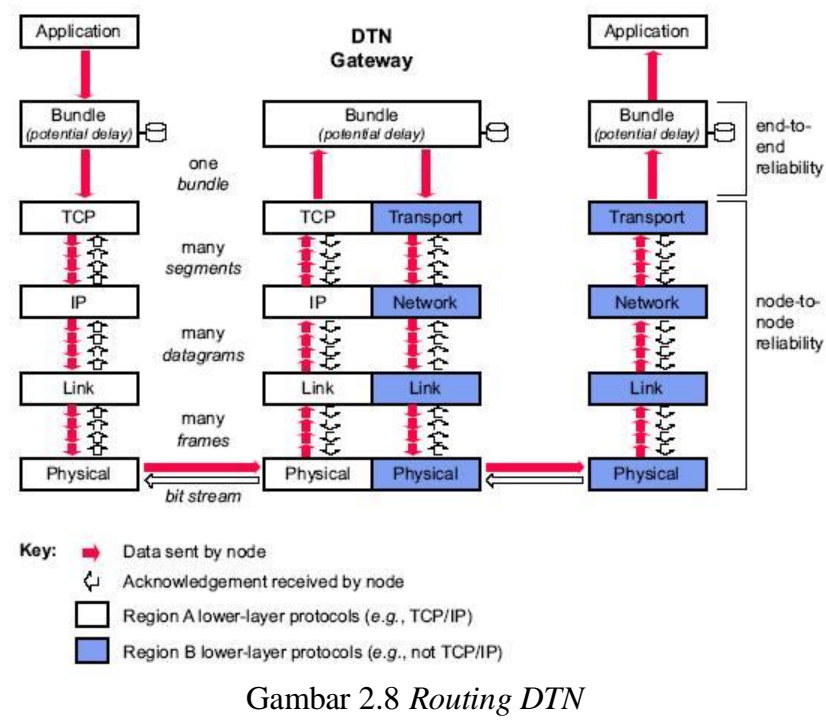

\subsection{DTN 2}

DTN2adalah nama perangkat lunak yang mengimplementasikan protocol Delay Tolerant Network (DTN). DTN2berperan sebagai standar aplikasi DTN. DTN2mengimplementasikan protokol DTN sesuai spesifikasi yang tercantum pada RFC 5050. DTN mengirimkan data dalam bentuk bundle yang mungkin bisa berukuran lebih besar dari besar paket yang umum pada jaringan IP. DTN2 dan IBR-DTN juga mendukung protokol bundle security untuk menyediakan fasilitas autentikasi pada bundle jika diperlukan. Bundle dapat dikirimkan melalui TCP/IP ataupun protokol lain. DTN2juga menyediakan mekanisme routing sehingga bundle dapat dikirim baik secara langsung ke tujuan maupun melalui router.[7][12] 


\section{BAB III}

\section{METODE PENELITIAN}

\subsection{Waktu dan Tempat}

Waktu pelaksanaan penelitian akan dilakukan selama 3 bulan, yaitu pada bulan juni sampai September 2017. Sedangkan lokasi penelitian dan pengujian akan dilakukan di Laboratorium Teknik Komputer Fakultas Sains dan Teknologi UIN Sultan Syarif Kasim, sebelum nantinya diimplementasikan pada kawasankawasan yang membutuhkan layanan hasil penelitian ini.

\subsection{Model Jaringan dan Sistem Layanan Email}

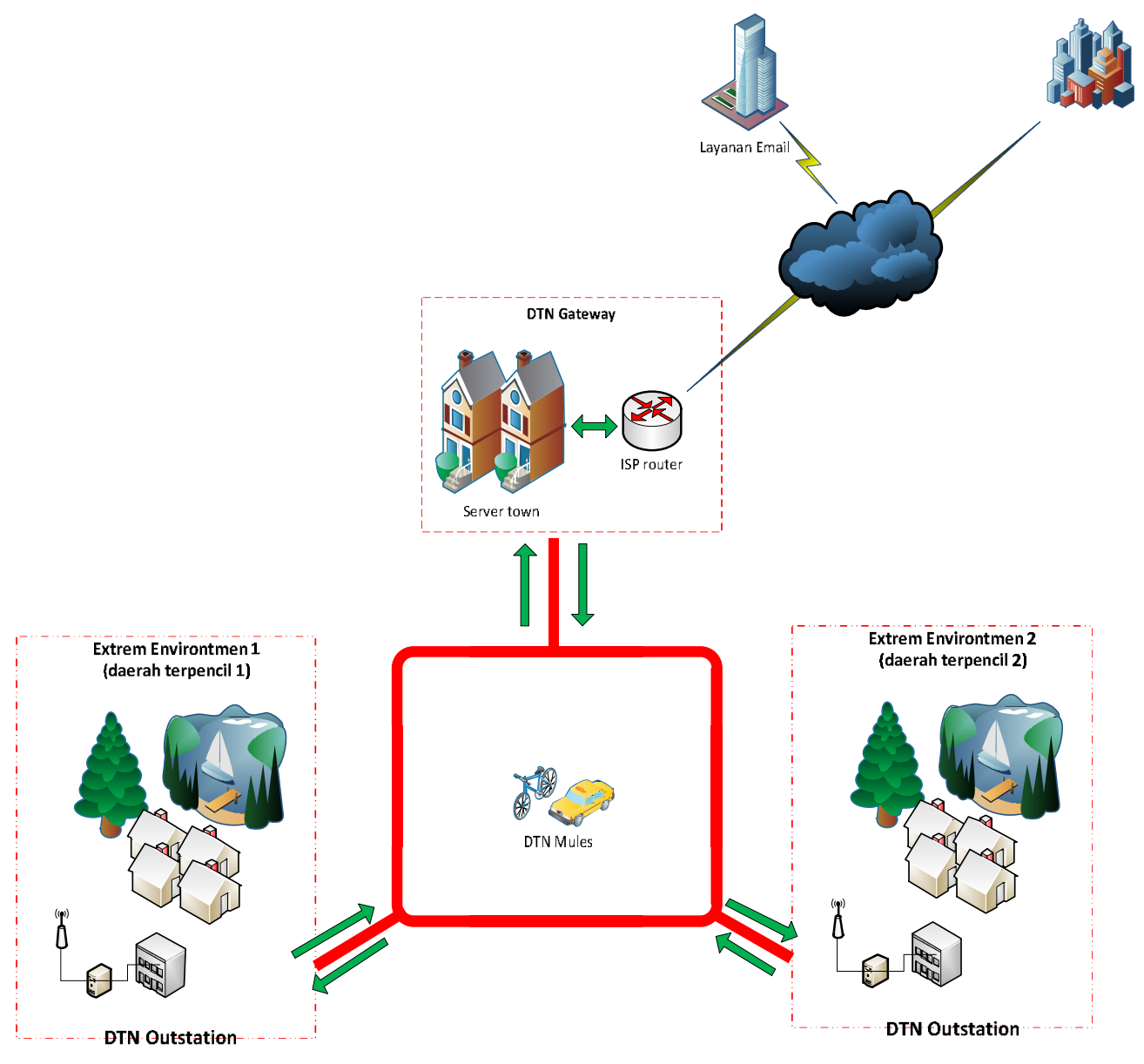

Gambar 3.1. Konsep Kerja Sistem 
Deskripsi umum model sistem, terpaparkan pada Gambar 3.1 diatas. Secara garis besar sistem dikelompokkan ke dalam sub bagian utama, yaitu DTN gateway, DTN mules, DTN outstation (ekstrim environment).DTN Gateway merupakan bagian node jaringan yang memiliki koneksi ke Internet Service Provider (ISP) yang menjembatani antara jaringan DTN dan internet global. Koneksi antara DTN Gateway dan DTN Outstation yang berada di kawasan ekstrim, dilakukan dengan DTN mules yang berupa router bergerak dan melakukan perjalanan antara jaringan, dalam hal ini adalah pejalan kaki dan motor ataupun perangkat mobile lainnya. Sedangkan, DTN Outstation adalah titik akses ke kawasan desa terpencil dimana semua berkasemail akan dikirim atau diterima melalui node ini oleh pengguna DTN. Ketika pengguna DTN mengirimkan email. Maka, email akan disimpan di DTN Outstation sampai DTN mules berada dalam jangkauan akses poin-nya akan mengambil email dan mengirimkannya ke tujuan melalui DTN gateway. ketika email terikirim di DTN Outstation dan DTN mules tidak tersedia, maka email akan tetap disimpan di DTN Outstation untuk di kirim ataupun diterima pada hari berikutnya.

Mekanisme detail Gambar 3.1 diatasdapat dideskripsikan dengan mengasumsikan bahwa extreme environment tersebut merupakan daerah terpencil yang terletak ditengah hutan ataupun suatu kawasan di lembah dan di kelilingi oleh pegunungan. Jarak daerah terpencil-1 dengan daerah terpencil-2 diasumsikan berkisar antara $\pm 5 \mathrm{~km}$ dan masih berada dalam satu kawasan pemerintahan kecamatan. Diawali dengan Main server mengunduh setiap layanan email yang masuk di internet yang ditujukan oleh pengguna daerah terpencil tersebut. Hasil unduhan konten email pada layanan internet akan tersimpan di Main server yang kemudian akan di unduh oleh Server town melalui jaringan internet umum yang terkoneksi ISP. Isi konten layanan email yang diunduh oleh Server town akan disimpan, yang kemudian akan disebar luaskan dengan menggunakan DTN mules (DTN Router) yang bergerak dengan cara mengunduh dan kemudian ditujukan ke setiap server yang berada ditiapdaerah terpencil. 
Ketika DTN mules(DTN router) melewati suatu lokasi daerah terpencil dan tercakup dalam jaringan wi-fi di daerah tersebut, DTN mules akan mengirimkan data ke server daerah terpencil yang telah diunduh sebelumnya dari internet. Bersamaan dengan itu pula, server di daerah terpencil akan mengirimkan data ke DTN mulesyang dibawa oleh kendaraan, berupa email dari pengguna daerah terpencil-1 yang ditujukan ke pengguna daerah terpencil lain dalam satu wilayah atau wilayah yang lainnya.

Jika suatu desa tujuan tidak terlewati atau telah terlewati oleh DTN mules, maka data email untuk daerah tersebut akan diteruskan dan diunggah ke server town untuk kemudian akan diunduh kembali oleh DTN mules lain pada waktu yang berbeda. Data email dari pengguna di suatu daerah terpencil yang ditujukan kepada pengguna layanan email di Internet akan diunggah ke Server town untuk kemudian diteruskan dan diunggah ke Main Server. Email dari pengguna di daerah terpencil yang ditujukan kepada pengguna layanan email di Internet diunggah oleh Server townke Main Server melalui jaringan Internet umum yang terkoneksi ISP. Email dari pengguna di daerah terpencil-1 ataupun -2 yang ditujukan kepada pengguna lainnya di Internet akan diteruskan ke jaringan Internet sesuai dengan tujuan dari email tersebut. 


\subsection{Tahapan Penelitian}

Tahapan Penelitian yang dilakukan adalah:

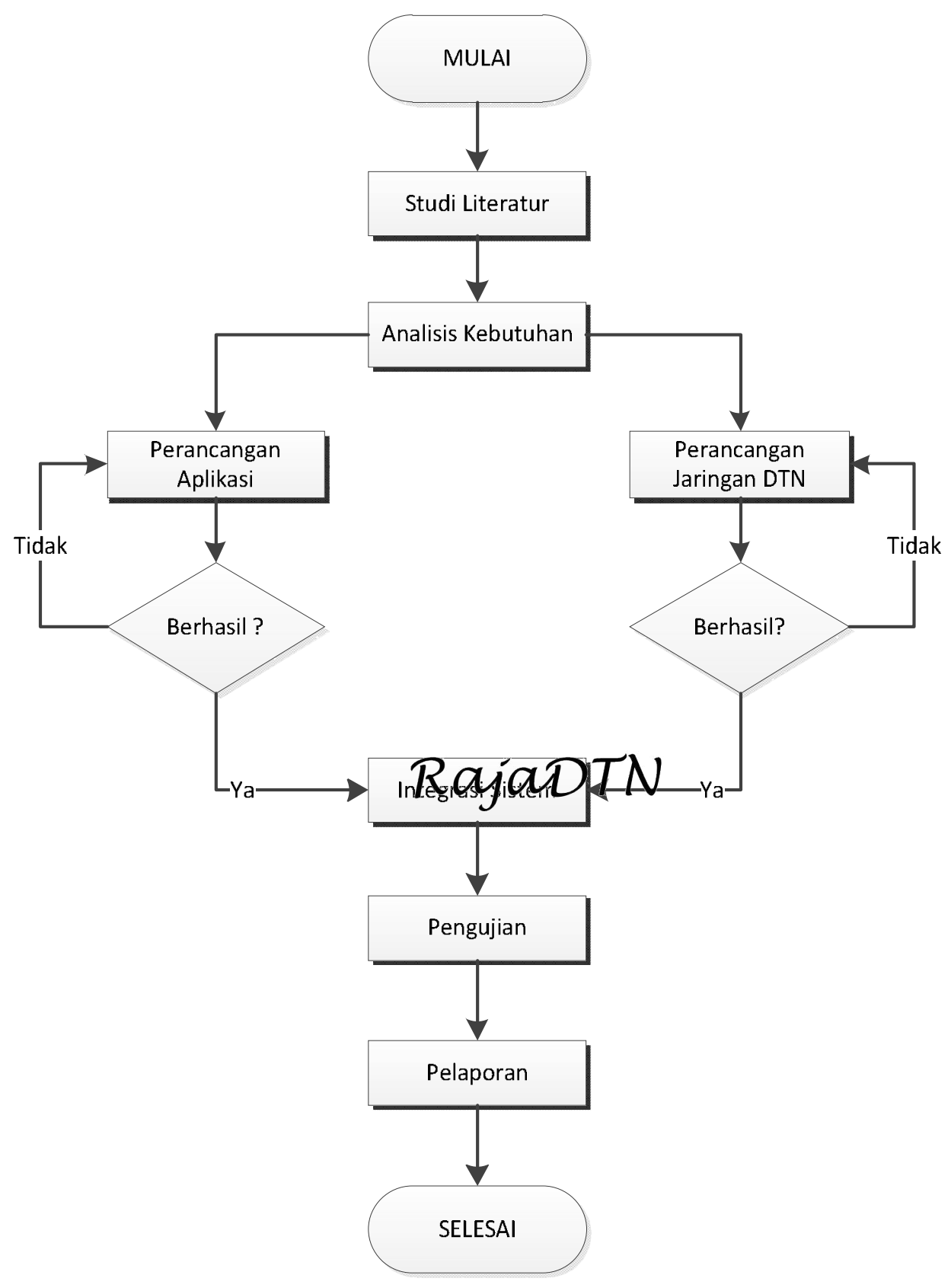

Gambar 3.2. Tahapan Penelitian 


\subsubsection{Studi Literatur}

Pada tahap ini akan dilakukan studi literatur tentang TCP/IP, DTN,DTN2, topologi transmisi data, macam-macam algoritma routing, instruksi-instruksi linux yang dibutuhkan, serta interfacependukungnya. serta data yang diambil adalahkemampuan server DTN dalam menangani email yang masuk.

\subsubsection{Analisis Kebutuhan Sistem}

Sebelum masuk ke tahap perancangan, perlu dilakukan analisa kebutuhan sistem. Proses ini penting dilakukan untuk memudahkan menginventarisir fitur yang dibutuhkan terkait perancangan.Pada Analisa kebutuhan sistem ini dikelompokkan kedalam dua Elemen Utama yang masing-masing adalah kebutuhan sistem dari layanan email menggunakan DTN dan kebutuhan system jaringan:

\subsubsection{Kebutuhan Sistem Layanan email}

Elemen yang digunakan dalam layanan email menggunakan jaringan DTN ini dapat dilihat pada Gambar 3.3 dibawah, dengan langkah-langkah seperti berikut:

1. Gmail merupakan Aplikasi email server untuk layanan internet global yang tentu tersedian aplikasi penerimaan dan pengiriman email.Setiap email dari pengguna yang terkoneksi jaringan internet Global akan diterima dan dikumpulkan oleh VPS. Kemudian dikelompokkan sesuai desa tujuan. Aplikasi kirim dan terima pada VPS difungsikan sebagai proses pengolahan setiap pengiriman dan penerimaan email yang masuk dari gmail maupun dari server kecamatan dan akan dikirimkan ke destinasi. Kemudian dikelompokkan dan disimpan sementara dalam bentuk bundle-mail.

2. Server Kecamatan merupakan server yang difungsikan sebagai tempat singgah sementara email dari jaringan internet global ataupun dari jaringan DTN desa sebelum nantinya didistribusikan ke tujuan dengan menggunakan Kurir DTN. Server kecamatan ini dilengkapi perangkat 
komputer yang berfungsisebagai gateaway yang menghubungkan antara sistem DTN dengan sistem non-DTN. Perangkat ini dilengkapi dengan aplikasi penerimaan danpengiriman email. Aplikasi penerimaan berfungsisebagai proses penerimaan setiap email yang masuk dari masingmasing outstasion atau desa melalui kurir yang menggunakan protokol DTN, sedangkan komunikasi antar server kecamatan ke server utama menggunakan metode tunneling SSH.

3. Kurir DTN merupakan kendaraan yang berfungsi sebagai DTN router untukmeneruskan data antara server kecamatan ke desa-desa menggunakan jaringan DTN. Kurir DTN ini nantinya akan secara otomatis terkoneksi dengan node-node DTN yang kemudian secara periodic setiap terjadi konektifitas akan mengambil paket berupa bundle-mail yang berada di server kecamatan ataupun di desa-desa.

4. Desa merupakan jaringan DTN outstation dimana computer yang difungsikan sebagai server email dengan aplikasi kirim dan terima email yang ditempatkan di desa untuk layanan masyarakat desa. Aplikasi kirim dan terima email ini difungsikan sebagai menangkap bundle-mail yang masuk ataupun yang akan dikirim dan berjalan pada backend sistem. Sedangkan untuk layanan interface email digunakan aplikasi email clientsquairrelmail. 


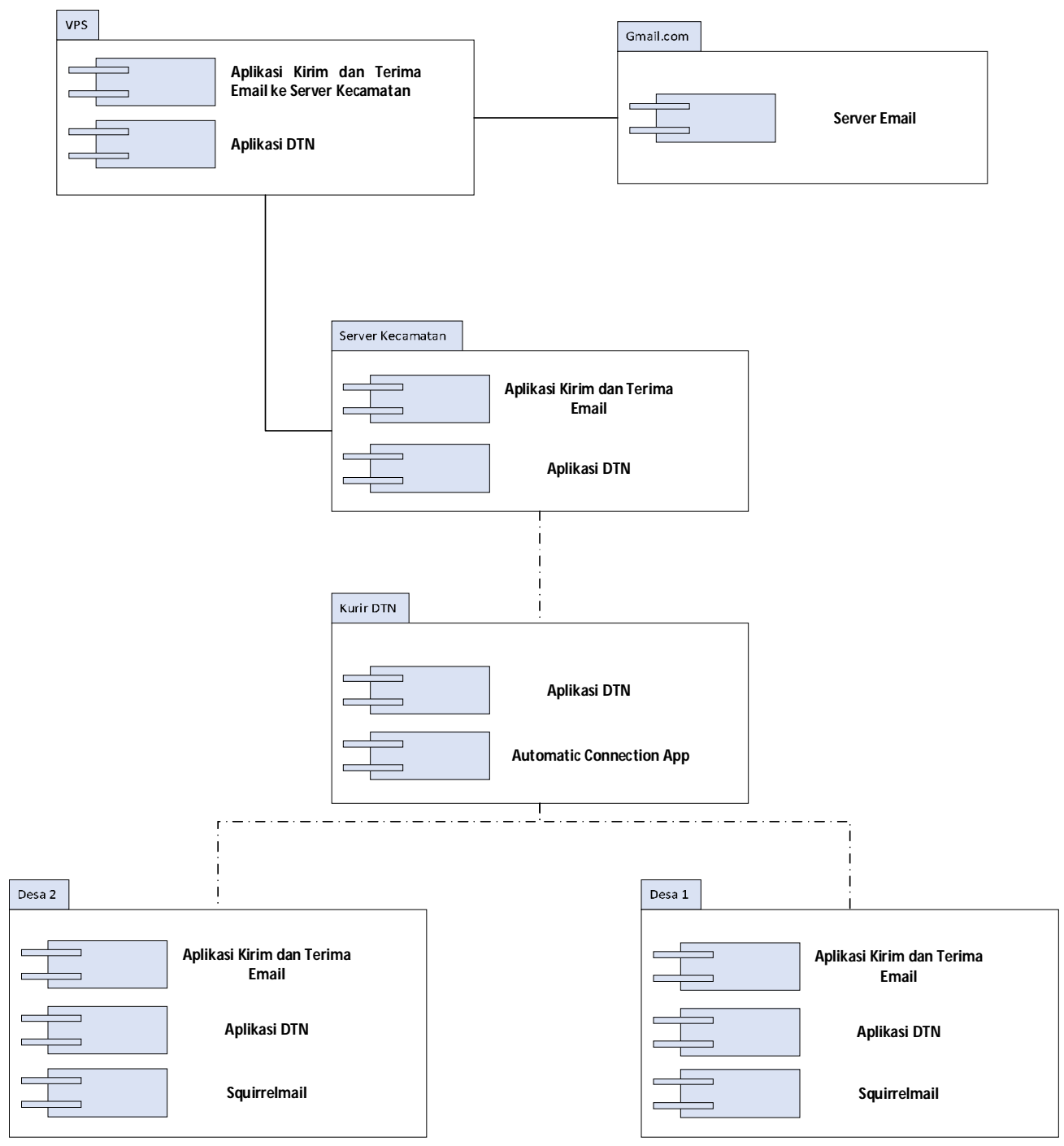

Gambar 3.3 Elemen penyusun layanan email menggunakan jaringan DTN

\subsubsection{Kebutuhan Sistem Jaringan}

Pada Kebutuhan Sistem Jaringan ini setiap perangkat dapat disesuaikan dengan kondisi daerah atau desa yang akan menggunakannya. Sehingga, biaya dalam pembuatan layanan email berbasis DTN ini akan relatif dapat di minimalisir. Sistem jaringan di bagi menjadi 2 bagian, yaitu pada sisi jaringan DTN dan Jaringan yang tidak menggunakan DTN.Seperti pada Gambar 3.4 berikut: 


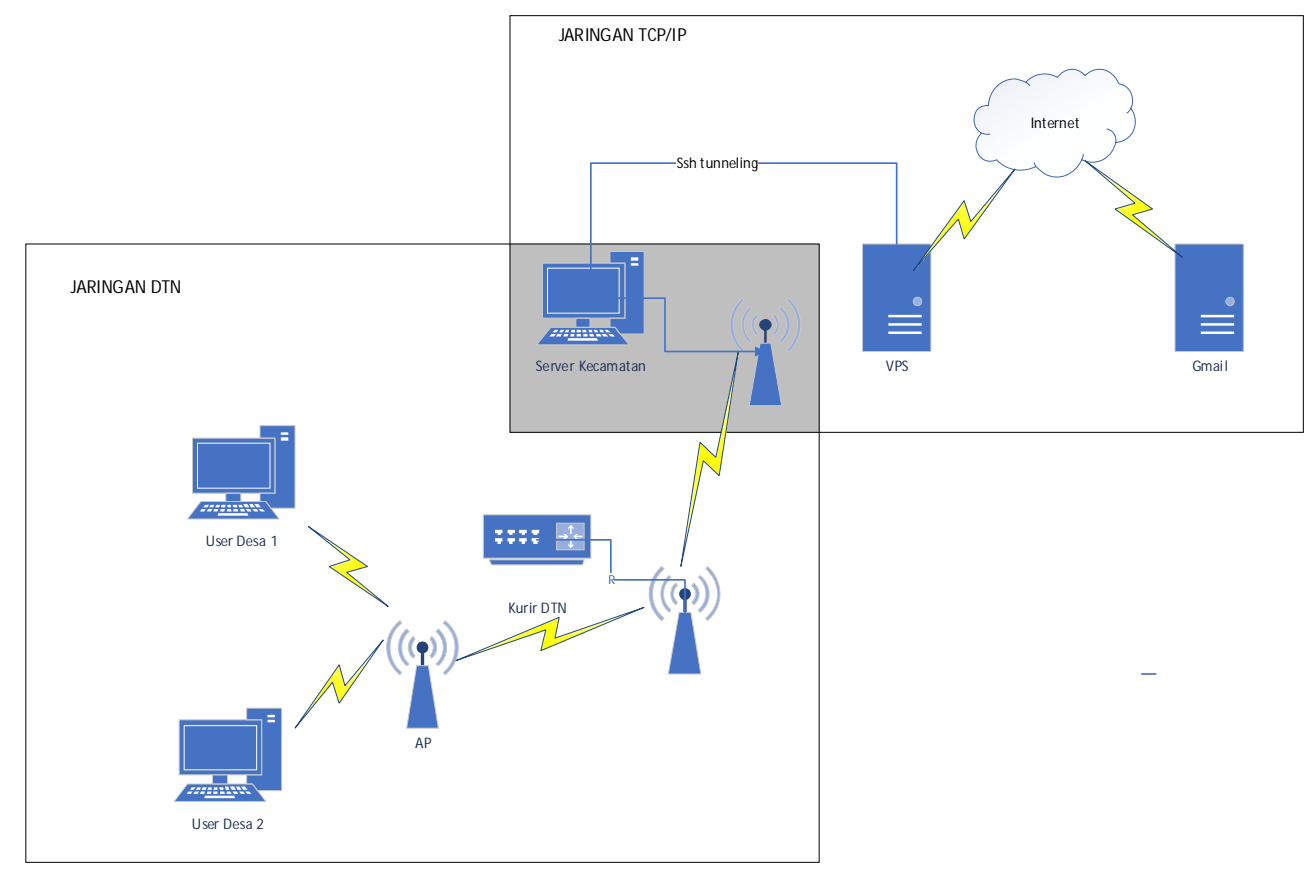

Gambar 3.4 Elemen Jaringan DTN Layanan Email

Elemen Penyusun Jaringan DTN adalah sebagai berikut :

1. Gmail berfungsi sebagai sarana penyedia aplikasi pengiriman email dari luar untuk pengguna diluar jaringan DTN.

2. VPS (Virtual private Server) berfungsi server utama dari jaringan DTN yang nantinya akan memberikan layanan email berupa manajemen email yang akan ditujukan dalam jaringan DTN ataupun ke internet global dalam hal ini Gmail.

3. Server Kecamatan berfungsi sebagai gateway antara sistem yang menggunakan jaringanTCP/IP dengan sistem dengan jaringan DTN. Komputer KPUD dilengkapi dengan perangkat Wireless Outdoor CPE yang diatur sebagai wi-fi access point (wi-fi AP) untuk menghubungkan Server Kecamatan dengan kurir DTN serta perangkat modem ADSL atau HSDPA untuk menghubungkan komputer Server Kecamatan ke komputer VPS melalui jaringan ISP dengan menggunakan metode ssh tunneling.

4. Kurir DTN dibangun menggunakan mikrokomputer odroid XU4, berfungsi sebagai DTN router. Kurir DTN dilengkapi dengan perangkat 
komputer Server Router. Untuk perangkat koneksi, Kurir digital dilengkapi dengan perangkat Wireless Outdoor CPE yang diatur sebagai DHCP client.

5. Access Point $(A P)$, berfungsi untuk menghubungkan antara server computer tiap desa dengan router yang melewatinya.

6. Komputer Server Desa merupakan suatu perangkat komputer untuk mengolah dan mengelola emai untuk masyarakat desa yang dilewati oleh kurir DTN. Untuk koneksi, Komputer Desa dilengkapi dengan perangkat Wireless Outdoor CPE sebagai wi-fi AP untuk menghubungkan Komputer ServerDesa ke Access Point ke Server Router di kurir DTN dan juga dari Komputer Server Desa ke Pengguna masyarakat desa.

\subsubsection{Perancangan Hardware}

Perangkat keras pada jaringan DTN dibagi kedalam beberapa kelompok, yaitu pada server kecamatan, kurir DTN dan server desa.Pada perancangan hardware ini dilakukan untuk konfigurasi IPpada setiap komputer yang akan digunakan untuk membangun jaringan DTN.

- Pada tiap Perangkat komputer di masing-masing node DTN diatas menggunakan sistem operasi Linux Debian 7 yang dilengkapi perangkat lunak DTN2 dan perangkat lunak email serversertastorage server untuk digunakan sebagai media penyimpanan data.

- Router Oudoor CPEuntuk menghubungkan tiap node dalam jaringan DTN.

- Modem USB GPRS/HSDPA untuk koneksi ke jaringan internet global Adapun konfigurasi IP dari jaringan DTN pada tiap node adalah sebagai berikut :

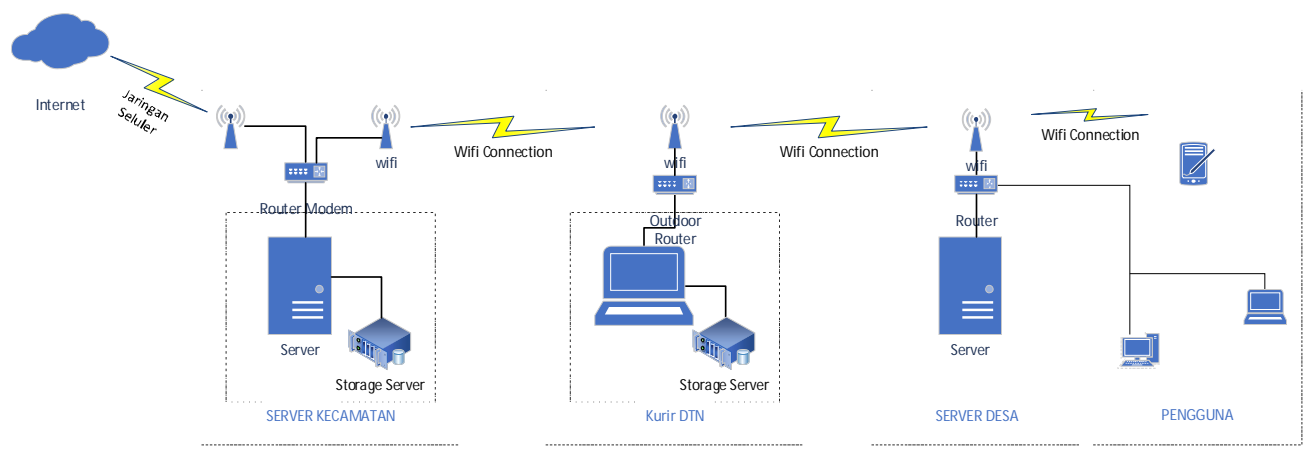

Gambar 3.5 Konfigurasi Jaringan DTN 
Tabel 3.1 Konfigurasi IP tiap node jaringan DTN

\begin{tabular}{|c|c|c|}
\hline Server Kecamatan & Kurir DTN & Server Desa \\
\hline 192.168 .10 .1 & DHCP Client Mode & 192.168 .11 .5 \\
192.168 .10 .5 & & \\
\hline
\end{tabular}

Keterangan :

Pada sisi server kecamatan IP di setting static dengan konfigurasi 192.168.10.1 yang akan digunakan untuk gateway yang terkoneksi dengan VPS dengan koneksi protocol TCP/IP. Sedangkan, IP 192.168.10.5 digunakan untuk konektifitas dalam jaringan DTN. Untuk Kurir DTN konfigurasi jaringan di setting sebagai DHCP client mode supaya mudah dalam autoconeksi ke masing-masing node nya.

Pada server desa di setting static dengan konfigurasi IP 192.168.11.5 dengan kelas yang berbeda dari server kecamatan. Karena, server desa ini disebut juga dengan (outstation) merupakan jaringan DTN tersendiri yang berada jauh di luar koneksi server kecamatan.

\subsubsection{Perancangan Software}

Pada bagian ini di bagi kedalam beberapa bagian perangkat lunak, yaitu :

\subsubsection{Instalasi dan Konfigurasi DTN2}

DTN2 merupakan aplikasi DTN yang berbasis unix yang dapat dijalankan pada Sistem Operasi Linux maupun windows. Pada penelitian ini OS yang digunakan adalah Debian 7. Konfigurasi DTN2 perlu dilakukan agar proses routing dalam jaringan DTN tidak mengalami lost routing. Sebelum melakukan konfigurasi Aplikasi DTN2 harus sudah diinstal terlebih dulu di OS linux sebelum di lakukan konfigurasi dengan perintah seperti berikut :

1. Melalui Terminal di di tiap OS Debian 7, ekstrak file dtn-2.9.0.tgz.gz dan oasys-1.6.0.tgz pada folder /dtn2 dengan urutan perintah sebagai berikut.

postmailekampoes: $\sim \mathrm{cd} / \mathrm{dtn} 2$

postmail@kampoes:/dtn2\$ sudo tar zxfv dtn-2.9.0.tgz.gz

postmailekampoes:/dtn2\$ sudo tar zxfv oasys-1.6.0.tgz.gz 
2. Instal oasys-1.6.0 dengan urutan perintah sebagai berikut.

postmail@kampoes: $\$$ cd /dtn2/oasys-1.6.0

: $\sim$ sudo . / configure

: $\sim$ sudo make

: $\sim$ sudo make install

Sebelum melanjutkan proses instalasi, lakukan modifikasi terhadap file SafeRange.h yang terdapat pada folder/dtn2/oasys-1.6.0/util/

Tambahkan baris berikut pada bagian deklarasi variabel (setelah baris 18) :

\#ifndef size_t

\#include <cstring>

\#endif

Untuk modifikasi file SafeRange.h pada folder /dtn2/oasys1.6.0/util/, dapat dilakukan dengan perintah sebagai berikut.

: \$ sudo nano/dtn2/oasys-1.6.0/util/SafeRange.h

Perintah nano akan menampilkan program text editorpada Debian 7. Setelah proses edit selesai, simpan file dengan menekan tombol ctrl O dilanjutkan dengan menekan Enter pada saat muncul pilihan untuk Save file kemudian ctrl $\mathbf{X}$.

3. Instal $d t n-2.9 .0$ dengan urutan perintah sebagai berikut.

$: \sim \$ \operatorname{cd} / \mathrm{dtn} 2 / \mathrm{dtn}-2.9 .0$

$: \sim$ sudo . / configure

: $\sim$ s sudo make

: \$ sudo make install

4. Buatfolder/home/postmail/dtndan/home/postmail/dtn/log_vps dengan perintah sebagai berikut.

: \$mkdir/home/postmail/dtn

: \$mkdir /home/postmail/dtn/log_vps

5. Salin file dtn.conf dari folder /dtn2/dtn-2.9.0/ ke folder /home/postmail/dtn dengan perintah sebagai berikut. 
$\$ c p-p / d t n 2 / d t n-2.6 .0 / d t n . c o n f / h o m e / p o s t m a i l / d t n /$

6. Salin file dtn.conf menjadi dtn.conf.ori untuk backup dengan perintah sebagai berikut.

\$cp $\quad-p \quad$ /home/postmail/dtn/dtn.conf

/home/postmail/dtn/dtn.conf.ori

7. Setelah instalasi selesai, sesuaikan parameter pada file dtn.conf menjadi seperti berikut.

\section{Pengaturan lokasi direktori payload}

Ubah baris berikut

storage set payloaddir \$dbdir/bundles

Menjadi

storage set payloaddir /home/postmail/dtn/bundles

Pengaturan lokasi direktori database $\mathrm{db}$

Ubah baris berikut

storage set dbdir \$dbdir/db

Menjadi

storage set dbdir /home/postmail/dtn/db

Pengaturan nama host local eid

Ubah baris berikut

route local_eid "dtn://[info hostname].dtn"

Menjadi

route local_eid "dtn://utama.kampoes.net"

$\underline{\text { Pengaturan jenis convergence layer interface dan local port }}$

Ubah baris berikut

interface add tcpo tcp

Menjadi

interface add tcp0 tcp local_port $=4556$

Pengaturan link dan alamat IP host/router 
Setelah baris berikut

\# link add link2 dtn2.dtnrg.org:1000 ONDEMAND tcp

Tambahkan

link add link1 router.kampoes.net:4556 ONDEMAND tcp max_retry_interval $=15$

Pengaturan route host DTN yang terhubung ke jaringan DTN

Setelah baris berikut

\# e.g route add dtn://host.domain/* tcp0

Tambahkan

route add dtn://*.kampoes.net/* link1

8. Inisiasi database pada program DTN2 dengan perintah sebagai berikut.

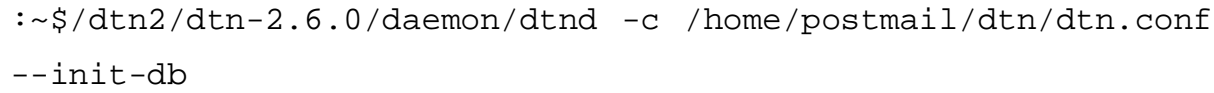

Jika proses inisialisasi berhasil, akan memberikan tampilan sebagai berikut.

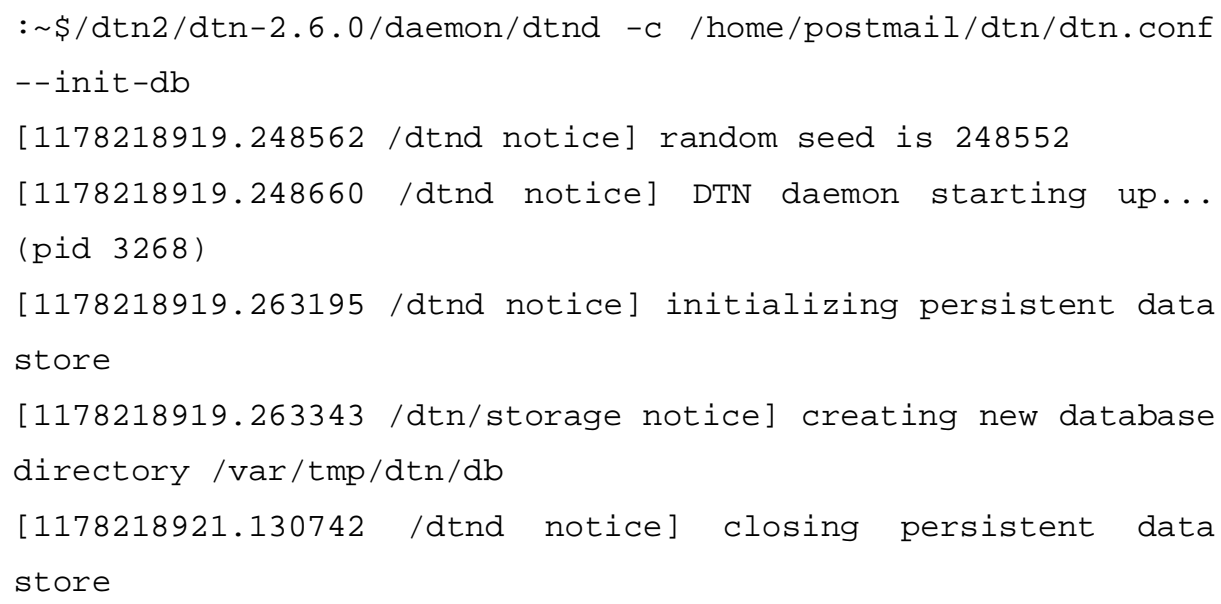

9. Salin file dtn.conf menjadi dtn_vps.conf dengan perintah sebagai berikut. 


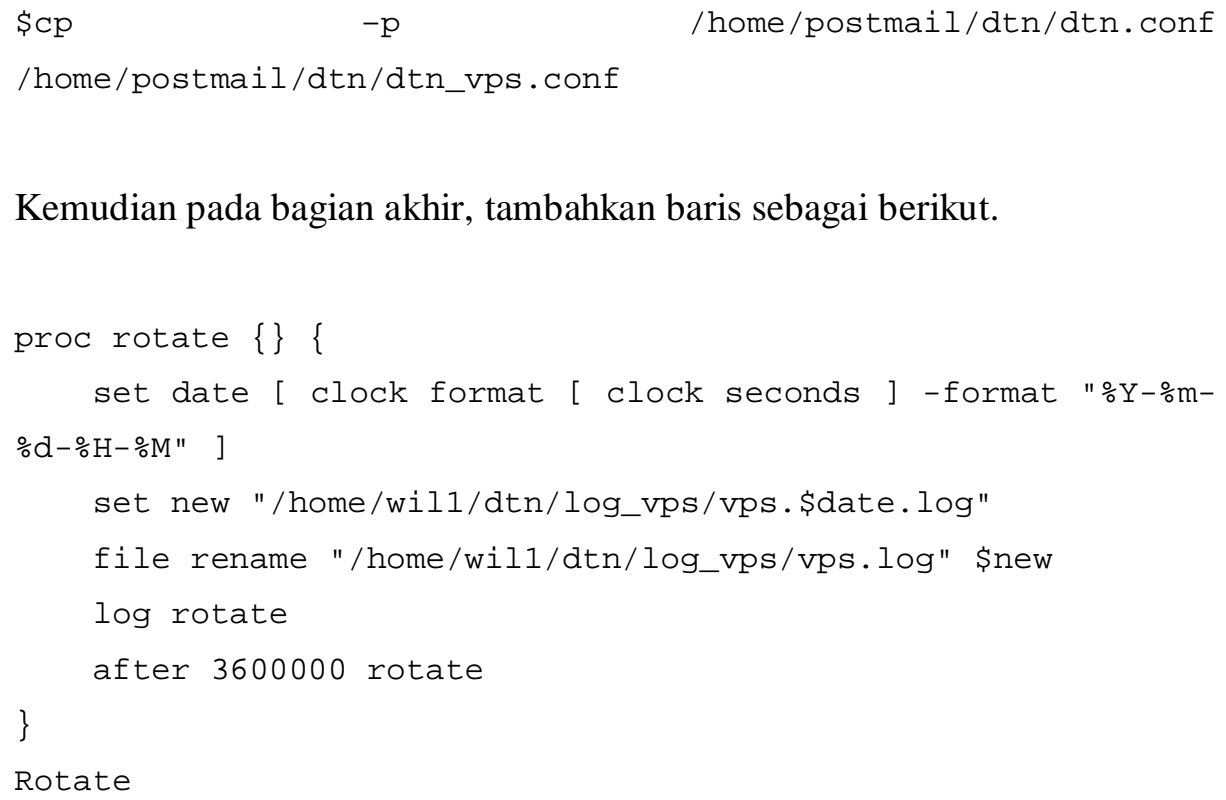

Kemudian pada bagian akhir, tambahkan baris sebagai berikut.

\subsubsection{Program Kirim dan Terima Email(Server Email)}

Program di buat dengan menggunakan Bahasa pemrograman shell Bash karena Sistem Operasi yang digunakan adalah berbasis linux (terlampir). Aplikasi ini berfungsi untuk mengintegrasikan antara aplikasi DTN2 dengan e-mail server yang akan dijalankan di backend system. Flowchart dari program aplikasi dapat di lihat pada Gambar 3.6 dibawah berikut ini: 

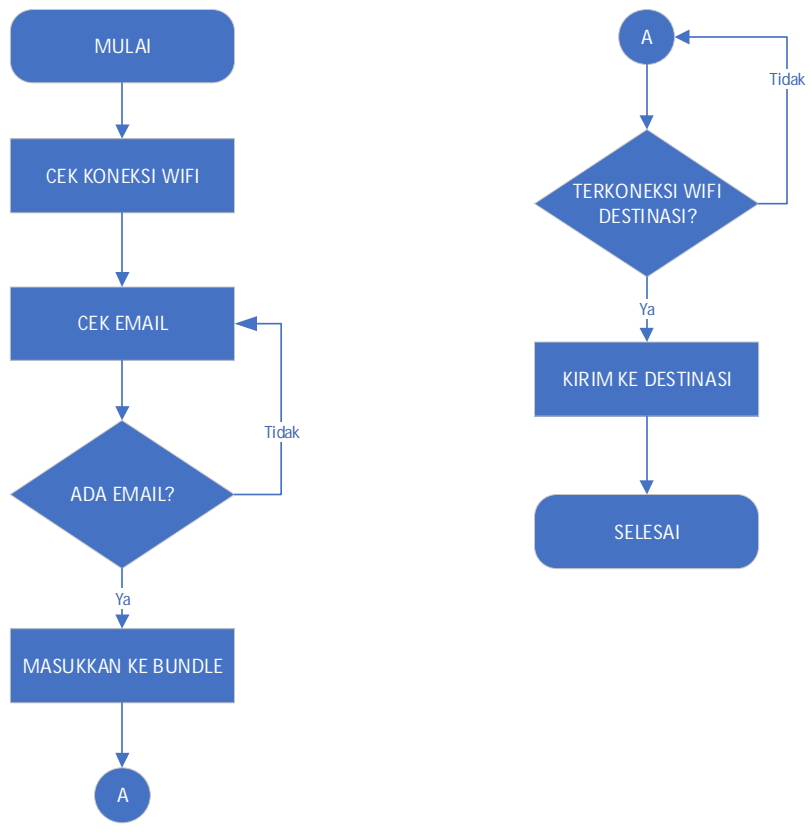

Gambar 3.6 Flowchart Program Kirim dan Terima Email

\subsubsection{Topology Jaringan}

Pada penelitina ini, menggunakan topologi dengan methode flooding, yaitu pengirim dalam hal ini kurir DTN akan bergerak mengirimkan email ke jaringan (destinasi) yang tetap. Konsep dari topologi ini dapat dilihat pada Gambar 3.7 dibawah ini :

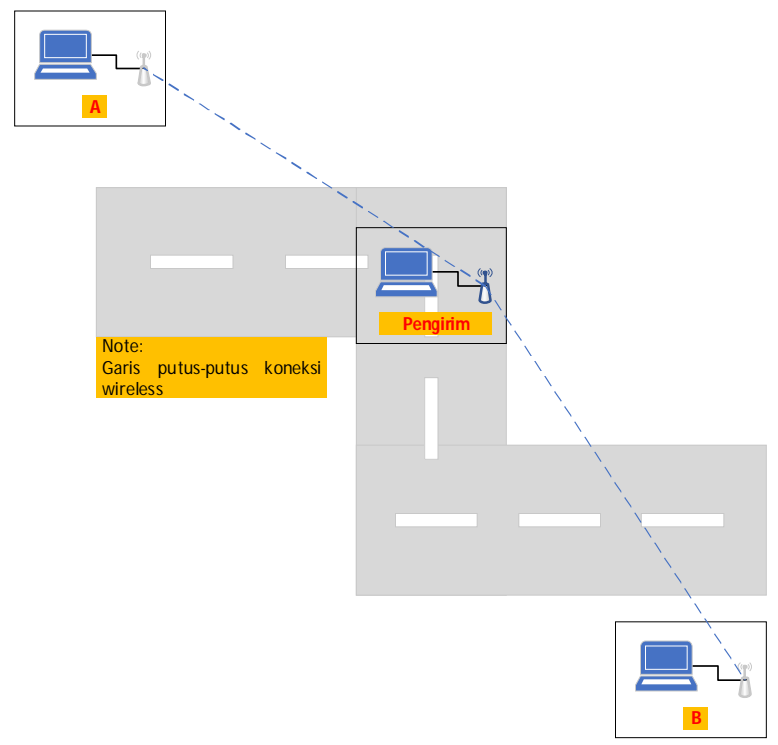

Gambar 3.7 Konsep Topologi dengan Metode Flooding 


\section{BAB IV}

\section{HASIL DAN PEMBAHASAN}

\subsection{Implementasi Sistem}

Implementasi dilakukan untuk menguji keberhasilan dari setiap aplikasipengiriman email yang telah dibuat dengan menggunakan Bahasapemrograman shell bash linux dan python. Hasil implementasi ditunjukkan pada Gambar 4.1 sampai Gambar 4.7 berikut ini :

\subsubsection{Implementasi Integrasi Aplikasi DTN2 dengan API Python}

Pada Terminal T1 di OS Debian uji program DTN2 dengan menjalankan perintah sebagai berikut.

: $\sim$ /dtn2/dtn-2.9.0/daemon/dtnd -c /home/vps/dtn/dtn.conf

Jika berhasil, maka akan keluaran akan memberikan tampilan sebagai berikut.

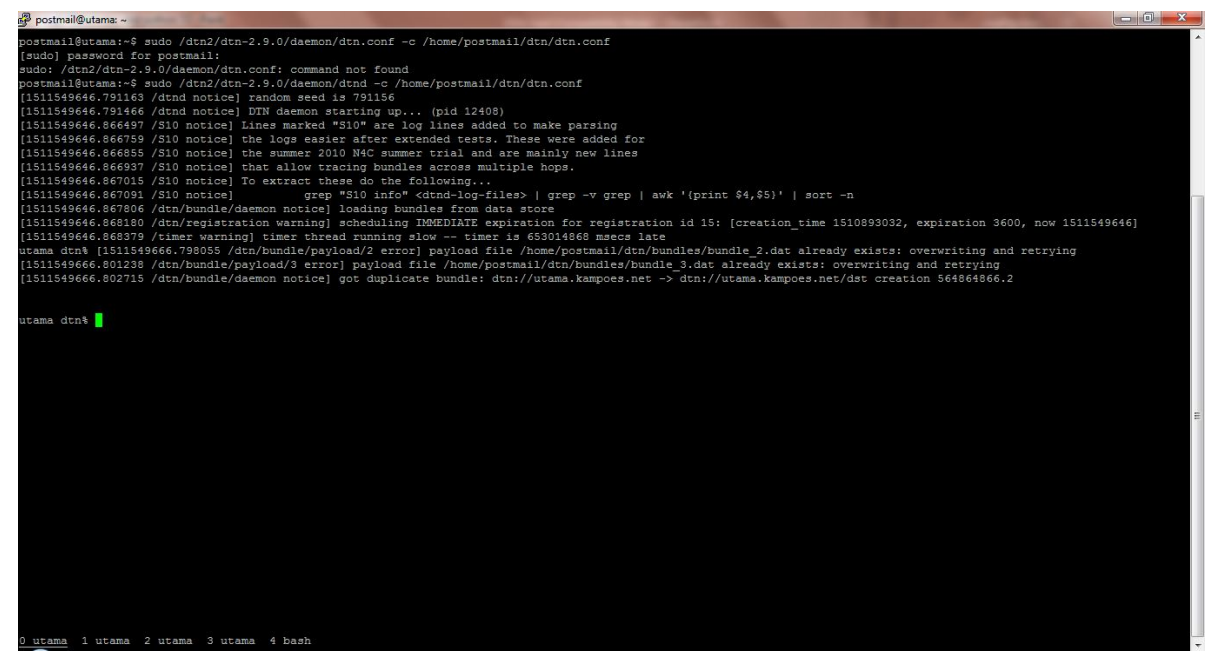

Gambar 4.1 Uji Aplikasi DTN2

Kemudian pada Terminal T2, ketikkan perintah berikut ini untuk melakukan pengujian Program pendukung sebagai server mail DTN berbasis Python :

: \$python Python/pypop/test-swig-api2.py 
Jika konfigurasi API Python telah berhasil, maka keluaran pada Terminal T2 akan memberikan tampilan sebagai berikut.

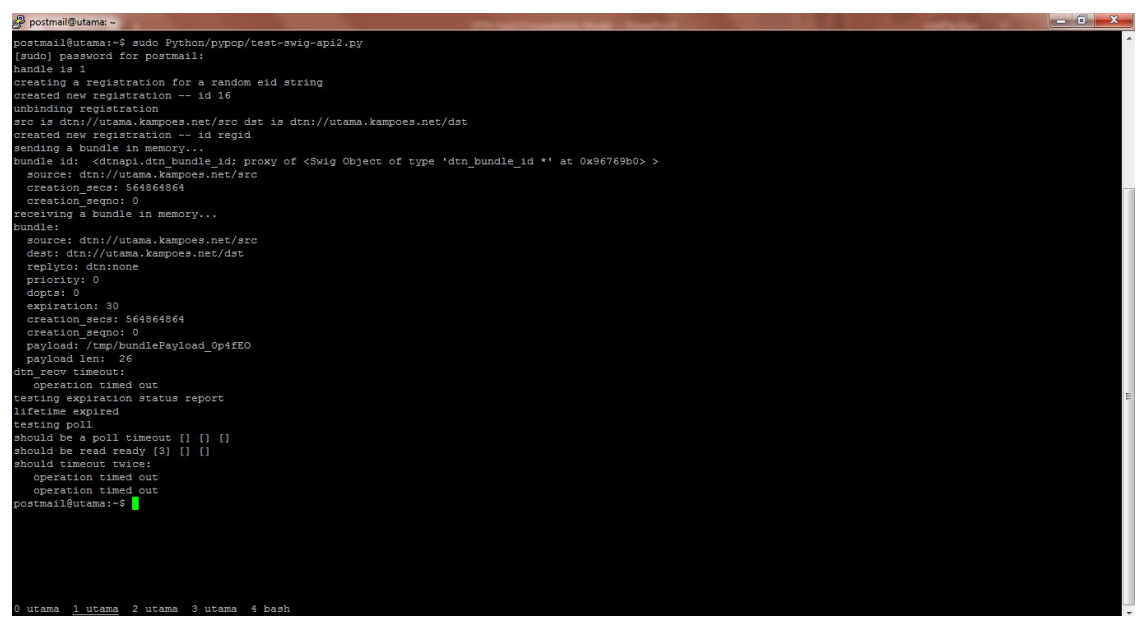

Gambar 4.2 Uji Integrasi Python

\subsubsection{Pengujian program aplikasi server email}

Aplikasi server email ini merupakan aplikasi untuk mengirim dan menerima setiap email yang kemudian dimasukkan ke dalam bundle DTN. Adapun implementasinya dilakukan dengan cara membuka aplikasi Terminal T1 pada Debian 7. Kemudian jalankan program aplikasi Email Server dengan perintah sebagai berikut.

kampoes@desa01: \$ sudo sh mulai.sh

Jika program aplikasi Email Server berhasil dijalankan, Terminal T1 akan memberikan tampilan seperti Gambar 4.3 sebagai berikut.

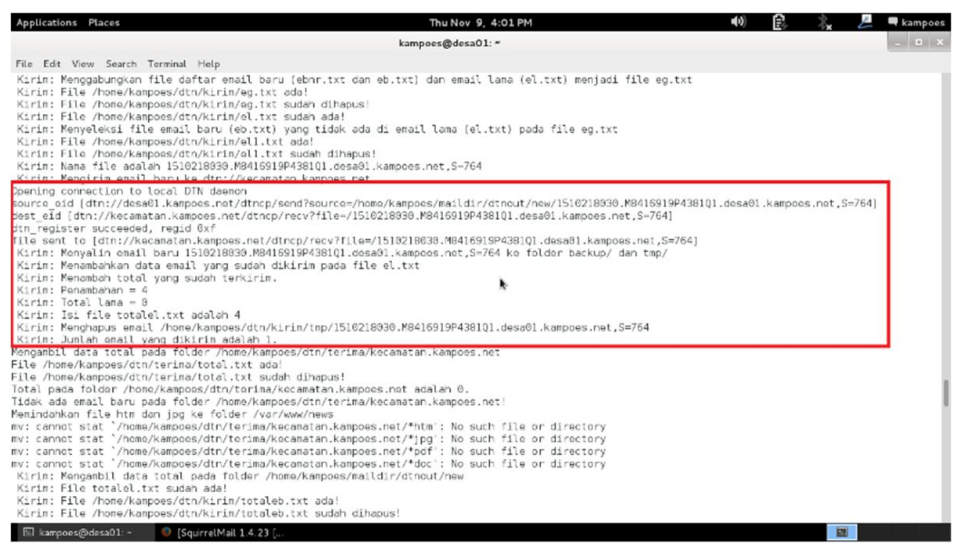

Gambar 4.3 Tampilan Aplikasi Server Email 
Seperti yang terlihat pada kotak berwarna merah diatas, bahwa setiap email yang diterima ataupun dikirim akan di tangkap oleh program aplikasi server email yang kemudian disimpan dalam bentuk bundle seperti pada Gambar 4.4 dibawah ini. Sebelum nantinya di teruskan ke setiap alamat tujuan oleh kurir DTN.
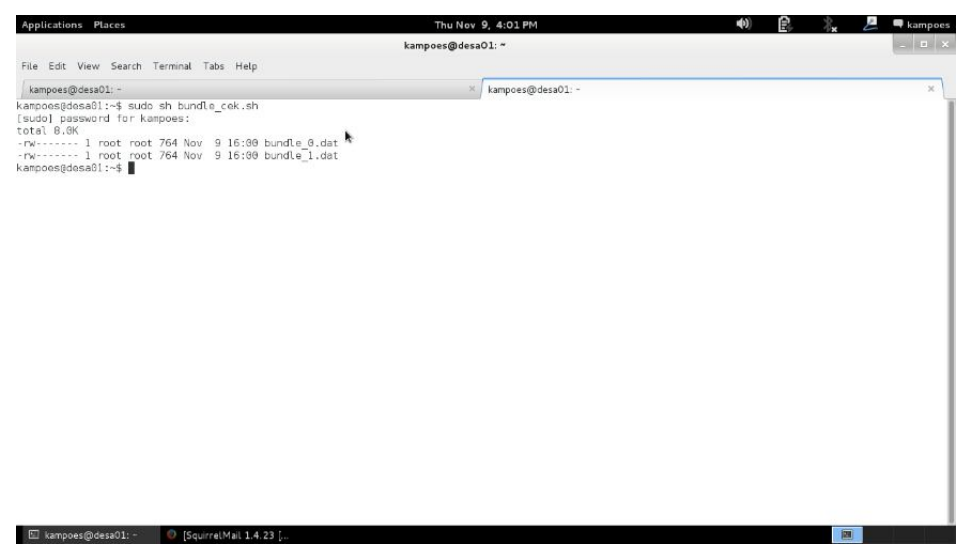

Gambar 4.4 Tampilan Email yang ter-Bundle

\subsubsection{Pengujian Aplikasi Squirrelmail}

Pada pengujian squirrelmail ini dilakukan dengan mengetikkan alamat domain di browser yang sudah di setting menggunakan bind, yaitu :

http://desa01.kampoes.net/squirrelmail

maka akan tampil aplikasi squirrelmail seperti pada Gambar 4.3 berikut yang akan digunakan sebagai sarana interface pengiriman dan penerimaan email pada sisi user.

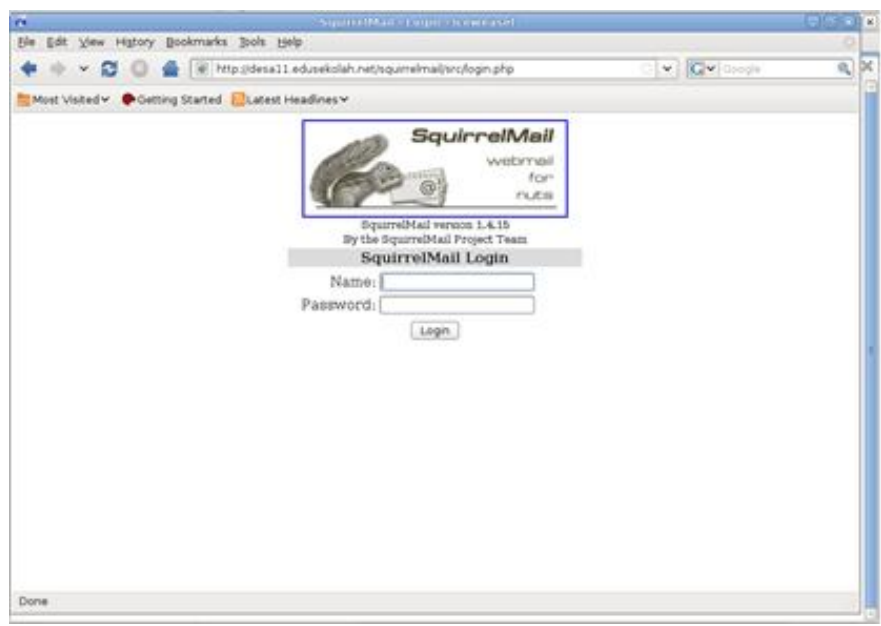

Gambar 4.5 Squirrelmail 
Setiap email yang terkirim akan terlihat seperti berikut.

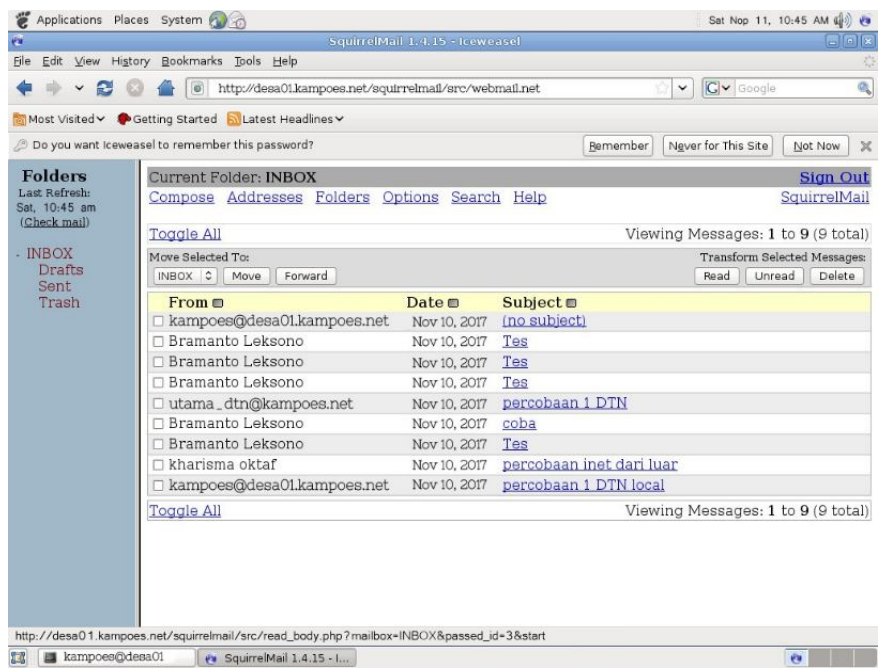

Gambar 4.6 Tampilan email yang diterima oleh user melalui jaringan DTN

\subsection{Pengujian Sistem}

Pengujian sistem layanan emaildilakukan dengan metode flooding, sebagai berikut :

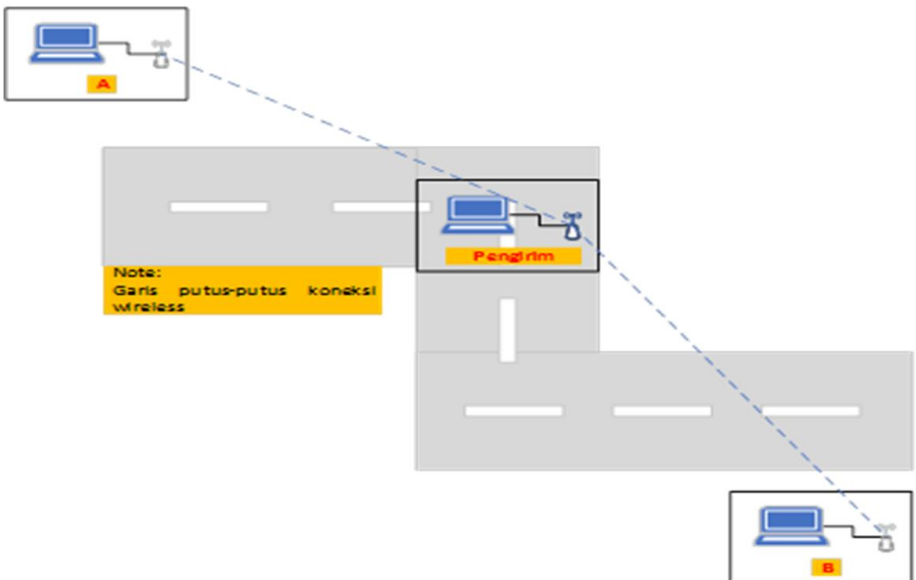

Gambar 4.7 Pengujian dengan metode flooding

Dilakukan dengan memodelkan beberapa komputer yang telah dikonfigurasi dengan perangkat lunak DTN2. Pengujian dilakukan untuk menganalisis kinerja router DTN sebagai kurir dalam transmisi data dan realibilitas paket email yang terkirim. DTN -mule (router DTN) yang berfungsi sebagai pembawa paket 
bundledari email sangat berperan penting dalam transmisi data. Sehingga, memerlukan kajian untuk mendapatkan efisiensi penggunaan router dalam sistem layanan email yang berada dalam jaringan berbasis delay tolerant network (DTN) ini.

Pengujian dilakukan dengan scenario flooding, seperti pada Gambar 4.7 diatas:

1. Pengirim akan mengirim file dari node A ke node B.

2. Pertama Sender akan terkoneksi dengan jaringan A.

3. Setelah 20 detik, sender berganti terkoneksi ke jaringan $\mathrm{B}$, dan setelah 20 detik ganti ke jaringan $\mathrm{C}$, dan balik ke $\mathrm{A}$, dan berulang setiap 20 detik sampai file terkirim ke node yang berada di jaringan D.

Hasil pengujian dapat di lihat pada table berikut ini :

Tabel 4.1 Pengujian Bundle Email

\begin{tabular}{|c|c|c|}
\hline Uji ke - & Data Email ter-Bundle (kB) & Flooding (time) \\
\hline 1 & 4.1 & $0: 01: 43$ \\
\hline 2 & 5.6 & $0: 01: 57$ \\
\hline 3 & 8.0 & $0: 02: 37$ \\
\hline 4 & 10.8 & $0: 03: 45$ \\
\hline 5 & 24.1 & $0: 02: 32$ \\
\hline 6 & 0 & $0: 00: 00$ \\
\hline 7 & 0 & $0: 00: 00$ \\
\hline
\end{tabular}

Grafik dari table diatas dapat dihasilkan seperti berikut.

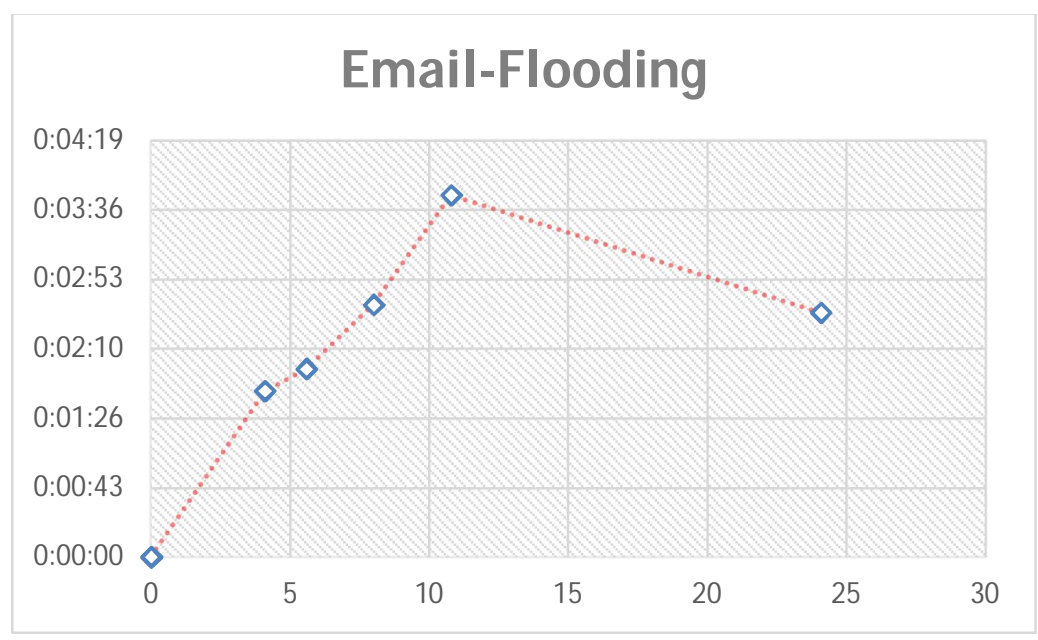

Gambar 4.8 Grafik ukuran email terhadap waktu 
Dari data diatas dapat dilihat bahwa metodeflooding dapat diterapkan pada ketiga tipe konfigurasi jaringan (Fix, Dynamic, dan Desa), jika sebuah node menggunakan metode ini maka bundle email yang akan dikirimkan ke tujuan akan dibroadcast ke semua node yang dikenalinya, sehingga setiap node yang dikenalinya harus mampu menampung data setiap kali proses transfer. Hal ini juga harus didukung dengan peralatan dalam transferdata yang memadai. 


\section{BAB V \\ KESIMPULAN}

Dari hasil penelitian ini dapat disimpulkan bahwa :

1. Dengan menggunakan konsep DTN, dapat dibangun jaringan layanan internet untuk layanan surat elektronik (email) didesa daerah terpencil, jaringan selular HSDPA, dan jaringan WiFi, tanpa memerlukan pembangunan infrastruktur khusus serta dengan biaya yang lebih murah jika dibandingkan dengan menggunakan layanan komunikasi satelit.

2. Sistem sudah mampu untuk menangkap email menggunakan protocol jaringan DTN.

3. Program API Python yang di gunakan untuk integrase DTN2 dengan server email masih sering mengalami kegagalan (error). Sehingga, mengakibatkan masih sering terjadi dalam proses bundling setiap email yang akan dikirim ataupun di terima.

4. Perangkat pendukung jaringan yang digunakan telah tersedia dipasaran sehingga model jaringan layanan yang telah diuraikan pada makalah ini dapat mulai diterapkan untuk desa daerah terpencil di Indonesia.

5. Metode Flooding setiap bundle email yang akan dikirimkan ke tujuan akan dibroadcast ke semua node yang dikenalinya, sehingga setiap node yang dikenalinya harus mampu menampung data setiap kali proses transfer.

6. Dengan pemilihan jenis perangkat serta konfigurasi perangkat WiFi yang tepat, jangkauan perangkat WiFi di desa dapat disesuaikan dengan kondisi geografis dari desa tersebut sehingga jaringan layanan email dan news portal menggunakan konsep DTN dapat diterapkan di berbagai desa yang memiliki kondisi geografis yang berbeda-beda. 


\section{DAFTAR PUSTAKA}

[1] S. Kominfo, "Pengguna Internet Di indonesia 2016," 2016. [Online]. Available: http://statistik.kominfo.go.id/site/data?idtree=424\&iddoc=1516. [Accessed: 20-Mar-2017].

[2] Wikipedia, "Daftar Pulau di Indonesia," 2015. [Online]. Available: https://id.wikipedia.org/wiki/Daftar_pulau_di_Indo. [Accessed: 20-Mar2017].

[3] K. Dewi, "Sejarah dan Perkembangan Email,” 2015. .

[4] Wikipedia, "Surat Elektronik," 2016. [Online]. Available: https://id.wikipedia.org/wiki/Surat_elektronik. [Accessed: 20-Mar-2017].

[5] E. M. Husni and A. R. Sumarmo, "Delay Tolerant Network utilizing train for news portal and email services," Proceeding 3rd Int. Conf. Inf.

Commun. Technol. Moslem World ICT Connect. Cult. ICT4M 2010, 2010.

[6] L. Gao, S. Yu, T. H. Luan, and W. Zhou, Delay Tolerant Networks. 2015.

[7] Y. Ratna, W. Program, T. Informasi, and U. Brawijaya, "Digital Repository Materi Pembelajaran Bagi Daerah Tertinggal Berbasis Delay Tolerant Network ( DTN )," pp. 1-7, 2013.

[8] E. M. Husni and A. R. Sumarmo, "Designing a DTN-based Network for Delivering News Portal and Email Services to Remote Villages by Utilizing Train as a DTN Router," pp. 1-6.

[9] L. Amalia et al., "Penerapan Delay Tolerant Network ( DTN ) untuk Sistem Konsultasi Kesehatan Jarak Jauh Berbasis Web,” pp. 1-8, 2013.

[10] J. J. P. C. Rodrigues, Advances in Delay-toler ant Networks ( DTNs ), Woodhead P. elsevier, 2015.

[11] J. Waworundeng, "Perancangan Aplikasi Telemedika Dan Mekanisme Pengiriman Data Melalui Email Dalam Delay Tolerant Networks," 2011.

[12] Git-hub, "IBR-DTN," 2015. [Online]. Available:

https://github.com/ibrdtn/ibrdtn/wiki. [Accessed: 20-Mar-2017]. 


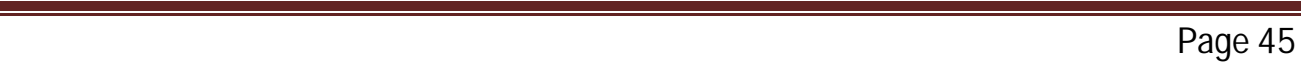




\section{BIODATA}

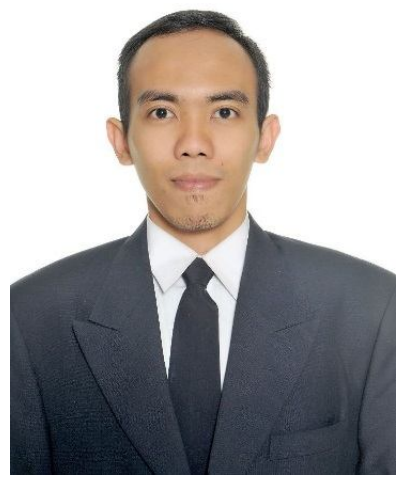

Oktaf Brillian Kharisma, ST., MT. Saat ini sedang menjadi seorang Dosen Tetap PNS pada Fakultas Sains dan Teknologi UIN Sultan Syarif Kasim Riau untuk jurusan Teknik Elektro.Sebelumnya pernah mengajar sebagai dosen Luar Biasa di Teknik Elektro pada Fakultas Sains dan Teknologi UIN Sunan Gunung Djati Bandung pada tahun 2014-2015. Pendidikan terakhir yang diperoleh adalah Master Teknik dari Institut Teknolgi Bandung pada tahun 2014 pada jurusan Teknik elektro bidang keilmuan Teknik computer. Bidang keahliannya saat ini adalah system embedded, beliau juga tertarik dibidang elektronika dan robotika. Selain itu, beliau juga sedang melakukan riset tentang pengembangan komunikasi DTN untuk satelit nano dibidang kemaritiman. 


\section{LAMPIRAN A}




\section{A. Infrastruktur Jaringan DTN}

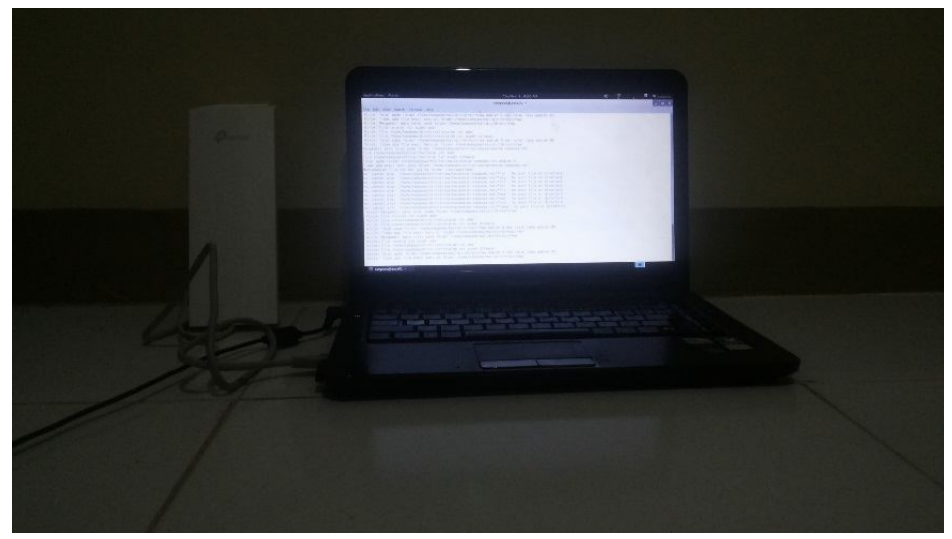

Gambar Komputer Server Desa

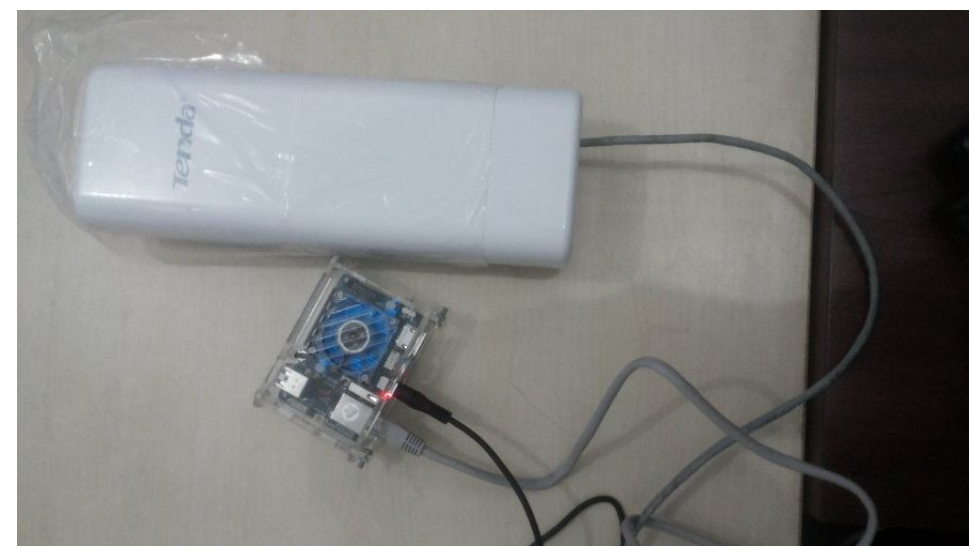

Gambar Kurir DTN

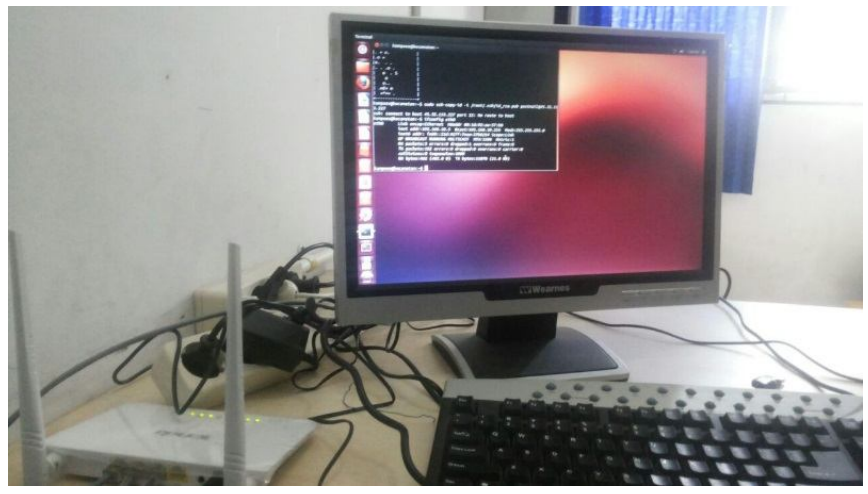

Gambar Server Kecamatan 


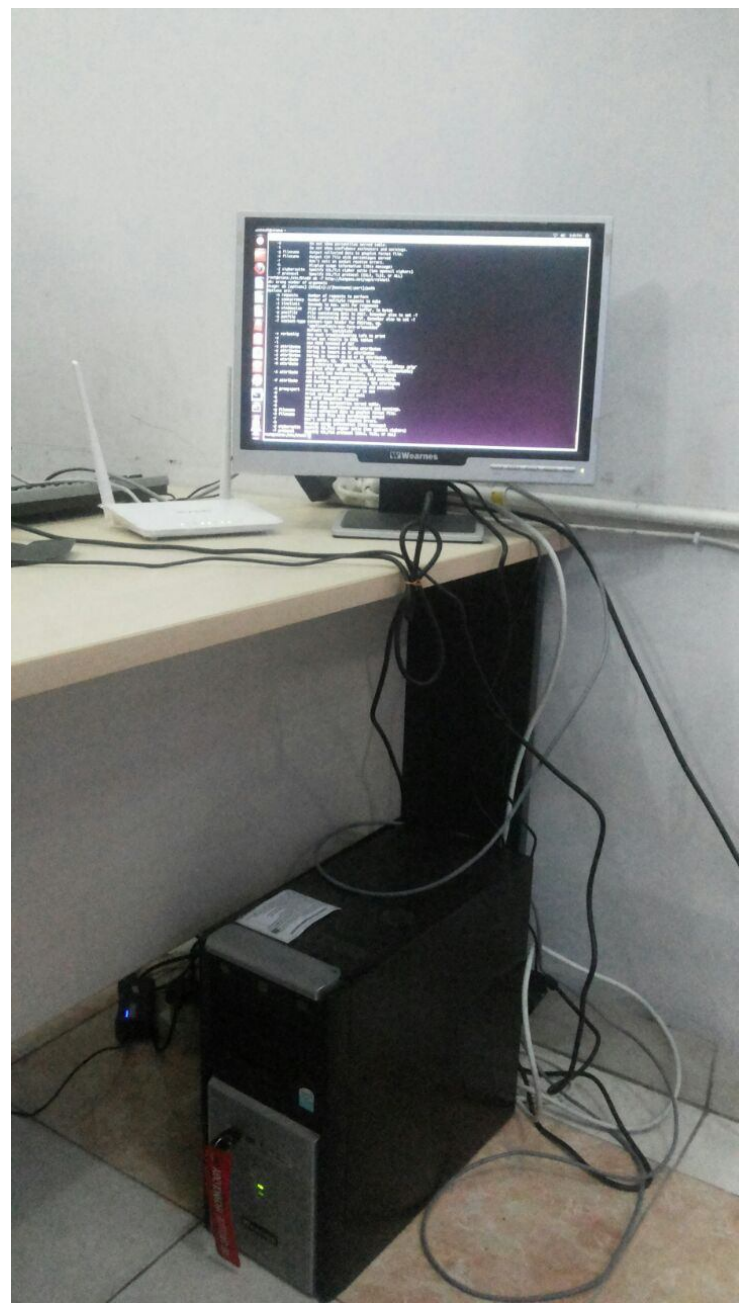

Gambar Komputer Server Kecamatan 
LAM PIRAN B

Page 50 


\section{Source Code Program}

\section{Listing Program Kirim.sh}

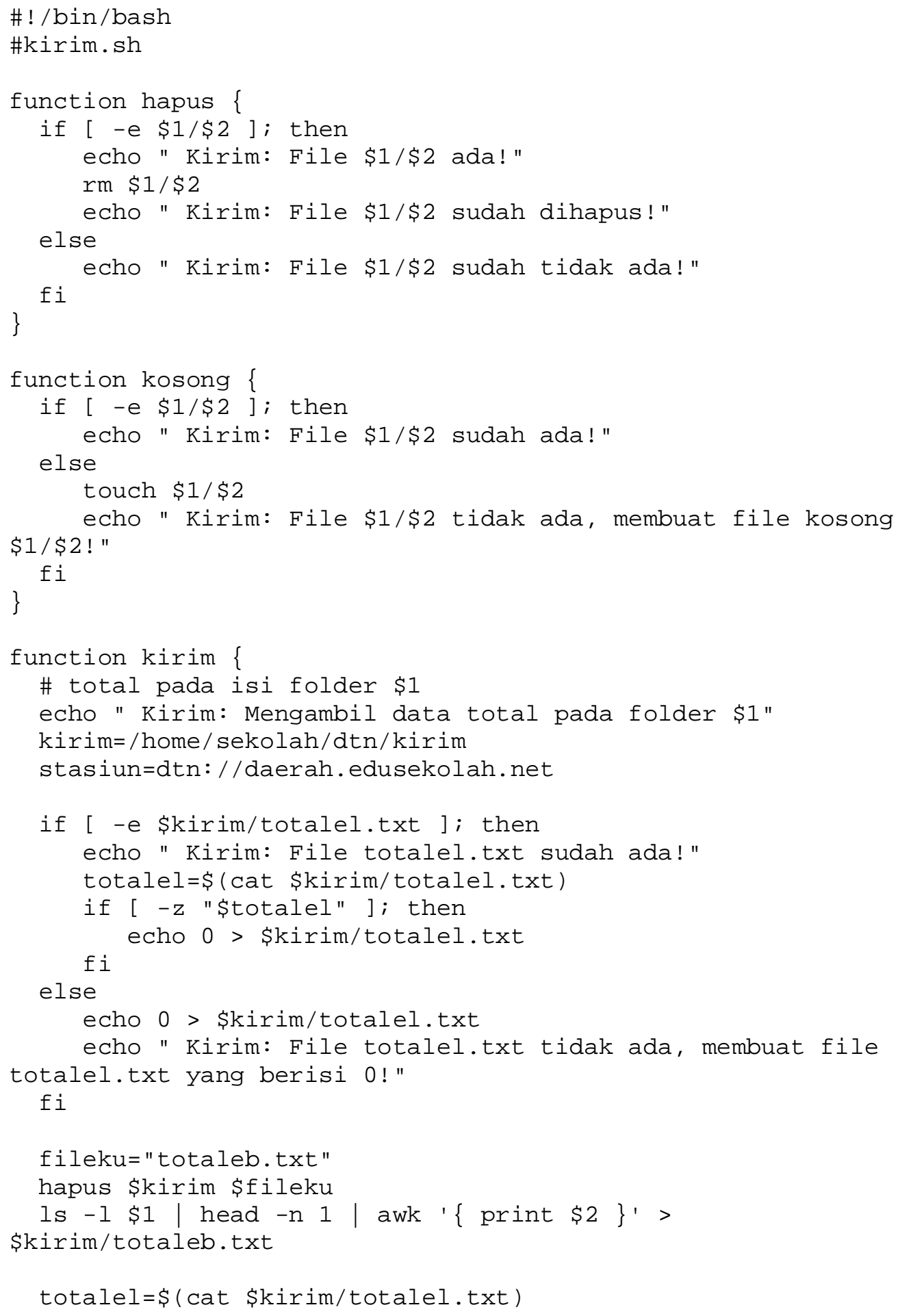


totaleb=\$(cat $\$$ kirim/totaleb.txt)

echo " Kirim: Total pada folder \$1 adalah \$totaleb dan total lama adalah \$totalel."

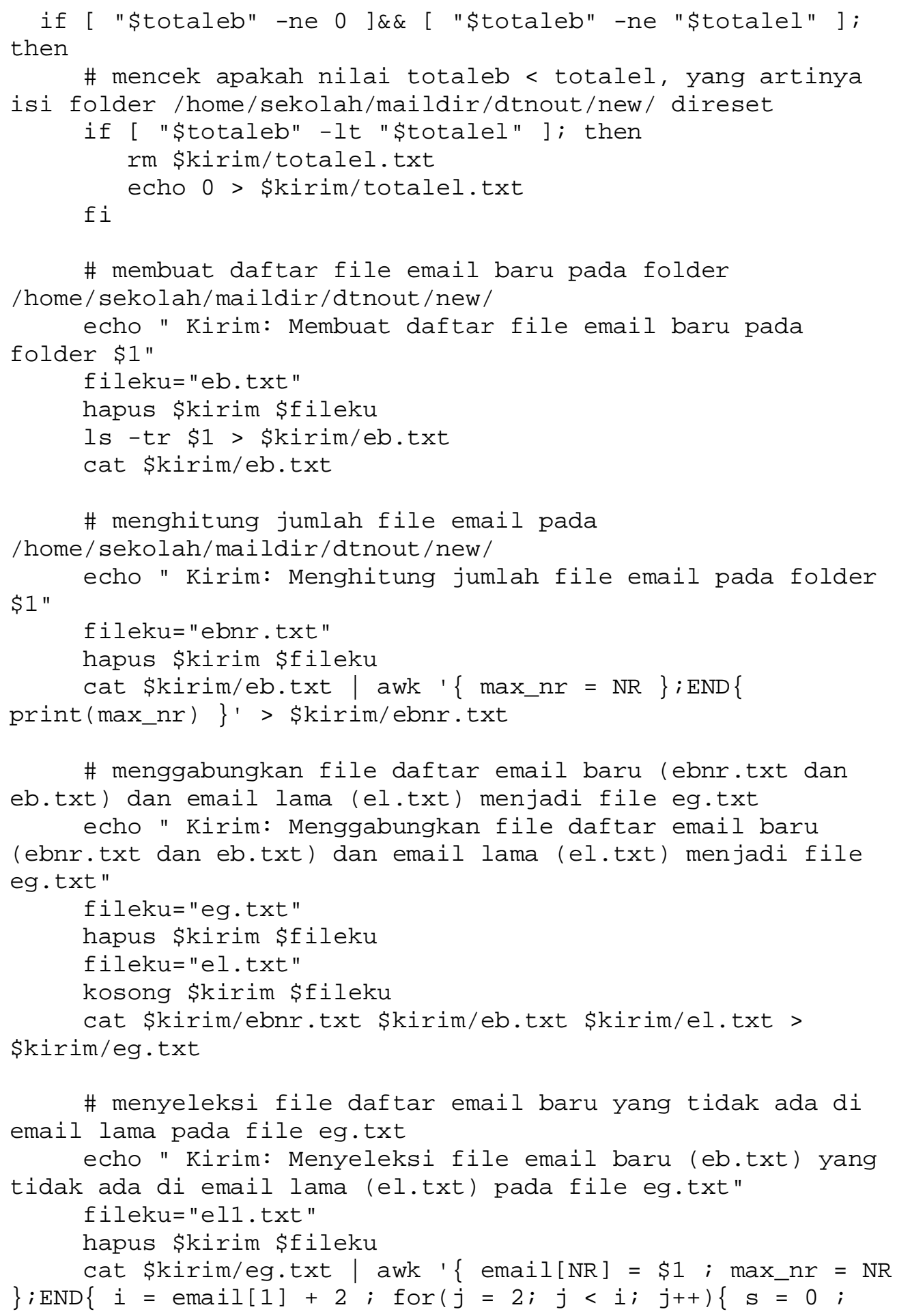




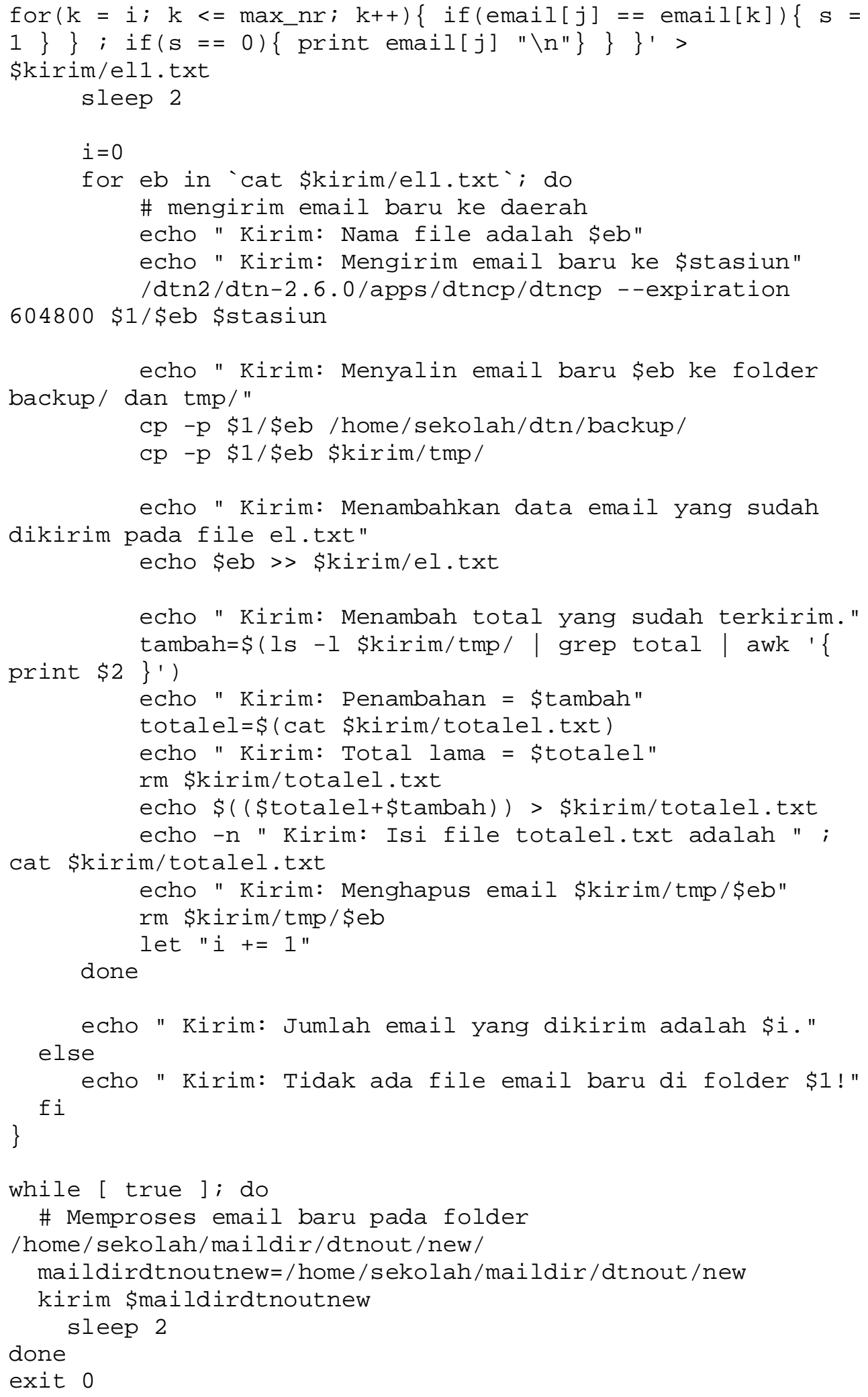




\section{Listing Program Terima.sh}

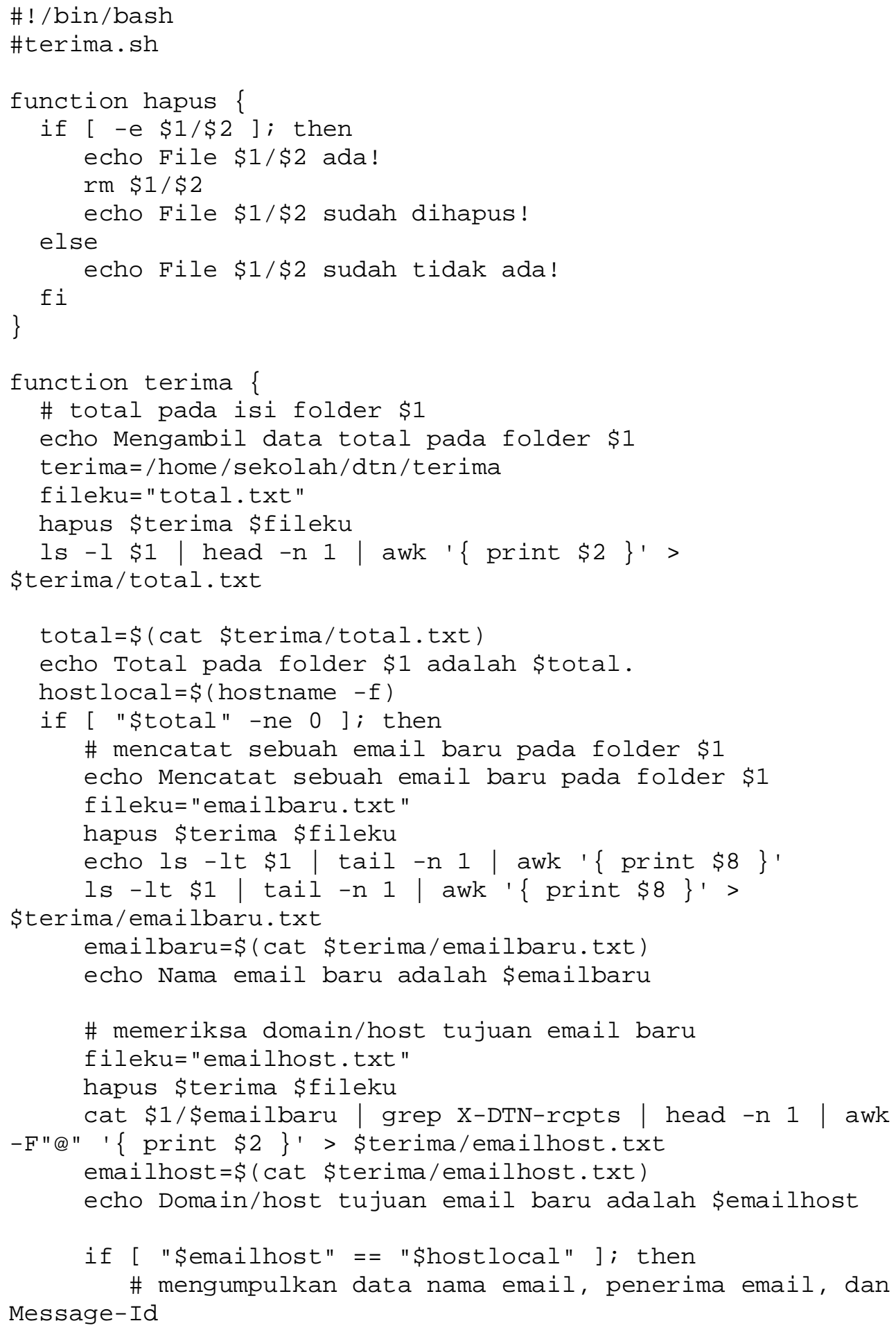


\# awalnya disimpan terpisah setiap baris di emaildata.txt kemudian digabung menjadi satu baris di emaildatal.txt

fileku="emaildata.txt"

hapus \$terima \$fileku

echo \$emailbaru > \$terima/emaildata.txt

cat $\$ 1 /$ Semailbaru | grep X-DTN-rcpts | head -n 1 |

awk '\{print $\$ 2$ \}' | awk -F"@" '\{print $\$ 1\}\}^{\prime}>>$

\$terima/emaildata.txt

cat $\$ 1 /$ emailbaru | grep -i "Message-Id: <" | head -

n 1 awk '\{ print $\$ 2\}$ ' | awk - F" $<"$ ' \{ print \$2 \}' awk -

F"@" '\{ print $\$ 1\}$ ' >> \$terima/emaildata.txt

fileku="emaildatal.txt"

hapus \$terima \$fileku

cat \$terima/emaildata.txt | awk ' \{ data[NR] $=\$ 1$

\};END $\{$ print data[1] ";" data[2] ";" data[3] \}' >

\$terima/emaildata1.txt

emailbaru=\$(cat \$terima/emaildatal.txt)

echo Data email baru adalah \$emailbaru

$\left.\$ 1\}^{\prime}\right)$

$s=0$

emailbarunama $=\$$ (echo \$emailbaru $\mid$ awk $-\mathrm{F} " ; "$ ' $\{$ print

print $\$ 2\}^{\prime}$ )

emailbarupenerima=\$(echo \$emailbaru $\mid$ awk $-\mathrm{F"} ; "$ ' \{

$\left.\$ 3\}^{\prime}\right)$ emailbaruId=\$(echo \$emailbaru | awk -F";" '\{ print

\# memeriksa isi file emaillama.txt

if [ ! -e \$terima/emaillama.txt ]; then

touch \$terima/emaillama.txt

fi

emaillama=\$(cat \$terima/emaillama.txt)

if [ -n "\$emaillama" ]; then

\# membandingkan nama email, nama penerima, dan

Message-Id email baru terhadap email lama

for emaillama in 'cat \$terima/emaillama.txt'; do

\# membandingkan nama email baru terhadap

email lama

echo Membandingkan nama email baru terhadap

email lama.

' $\{$ print $\$ 1\} '$ ') email lamanama $=\$$ (echo \$emaillama | awk -F";"

then

if [ "\$emailbarunama" != "\$emaillamanama" ];

\# membandingkan Message-Id email baru

terhadap email lama

echo Membandingkan Message-Id email baru

terhadap email lama. 


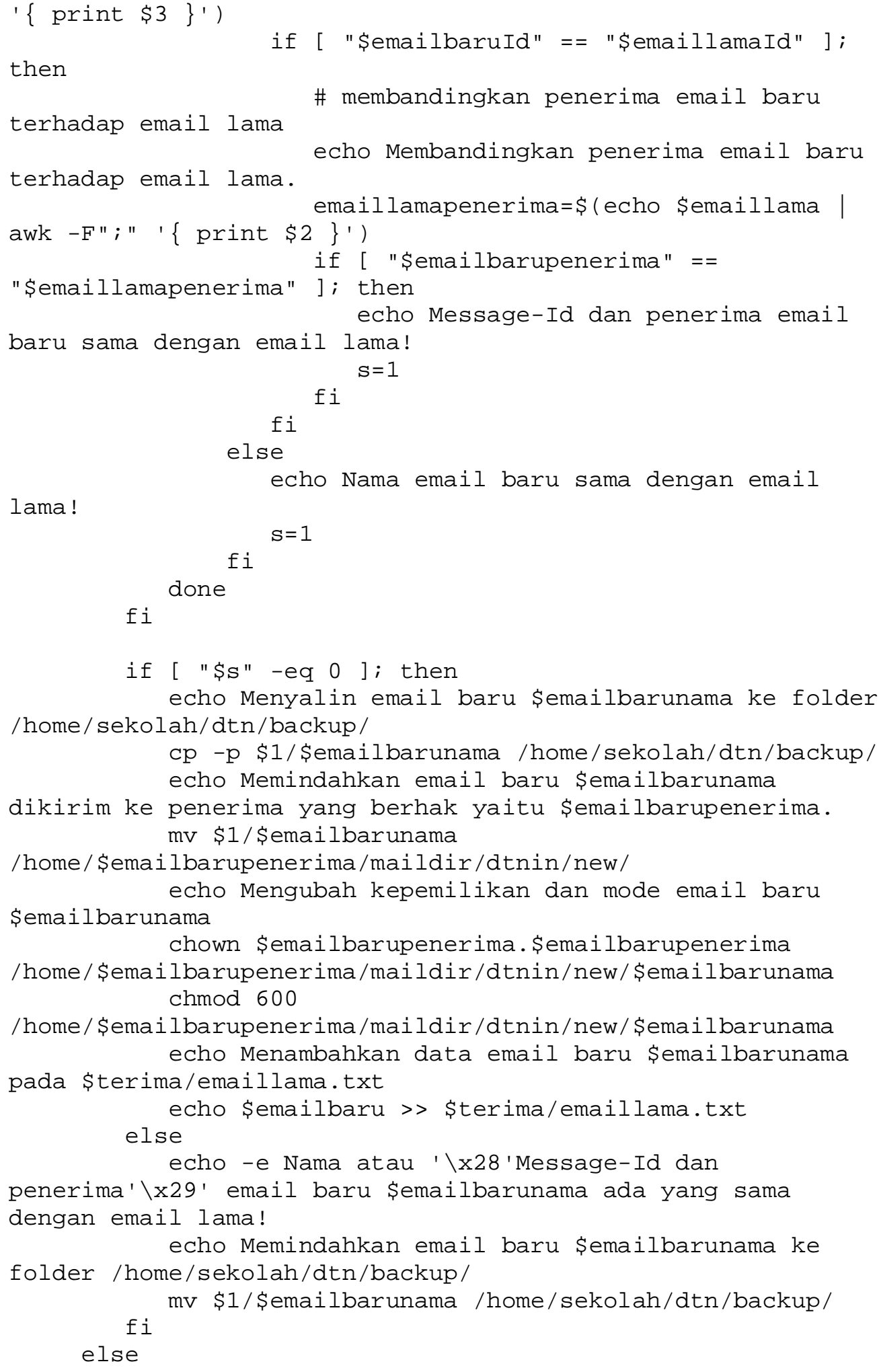

lama!

$s=1$

fi

done

fi

if [ "\$s" -eq 0 ]; then echo Menyalin email baru Semailbarunama ke folder /home/sekolah/dtn/backup/ cp -p \$1/\$emailbarunama /home/sekolah/dtn/backup/ echo Memindahkan email baru \$emailbarunama

dikirim ke penerima yang berhak yaitu \$emailbarupenerima. mv \$1/\$emailbarunama

/home/ \$emailbarupenerima/maildir/dtnin/new/ echo Mengubah kepemilikan dan mode email baru \$emailbarunama chown \$emailbarupenerima. \$emailbarupenerima /home/ \$emailbarupenerima/maildir/dtnin/new/\$emailbarunama chmod 600

/home/ \$emailbarupenerima/maildir/dtnin/new/ \$emailbarunama echo Menambahkan data email baru \$emailbarunama pada \$terima/emaillama.txt echo \$emailbaru >> \$terima/emaillama.txt else echo -e Nama atau ' \x28'Message-Id dan penerima' \x29' email baru \$emailbarunama ada yang sama dengan email lama! echo Memindahkan email baru \$emailbarunama ke folder /home/sekolah/dtn/backup/ fi mv \$1/\$emailbarunama /home/sekolah/dtn/backup/ else 


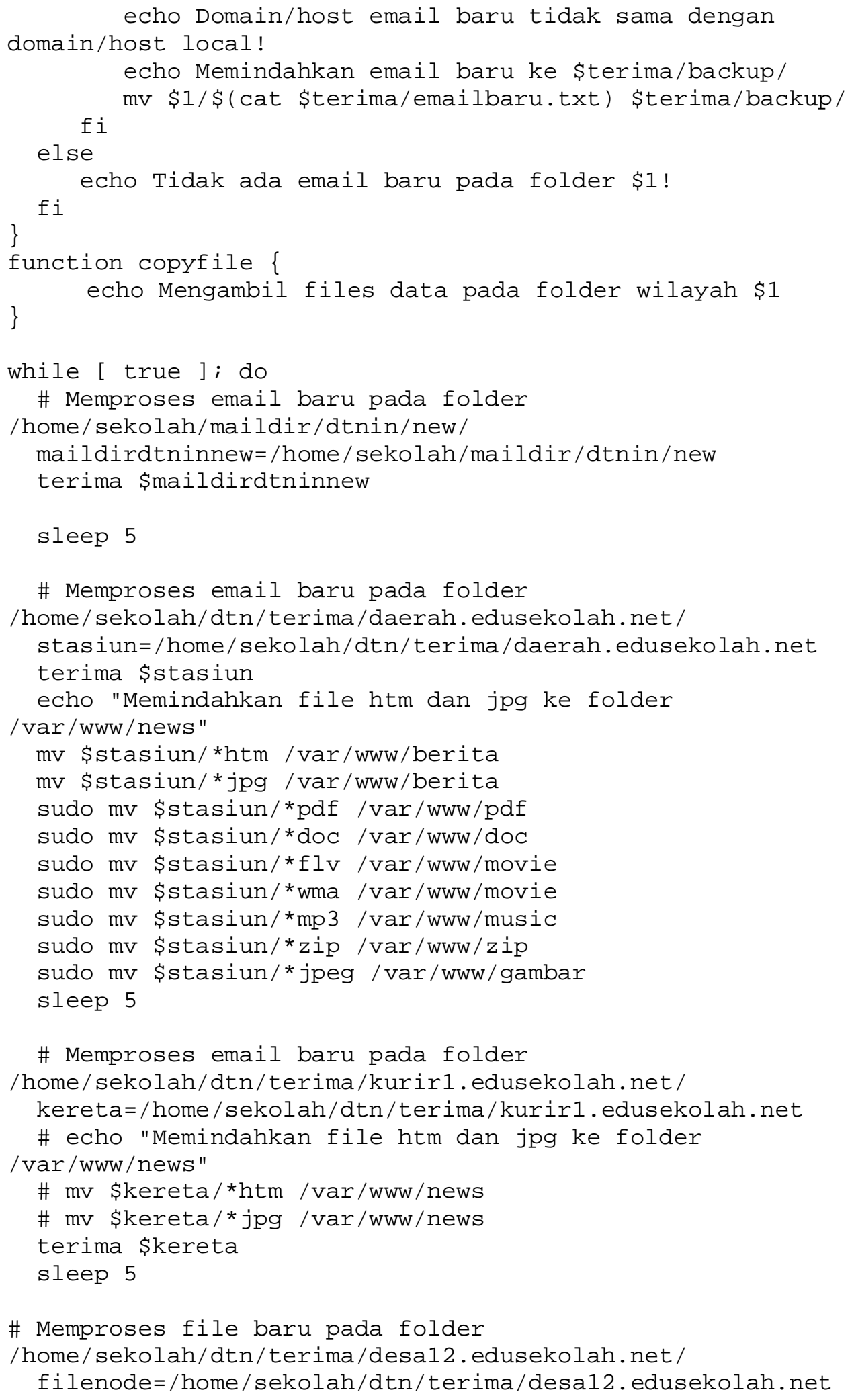




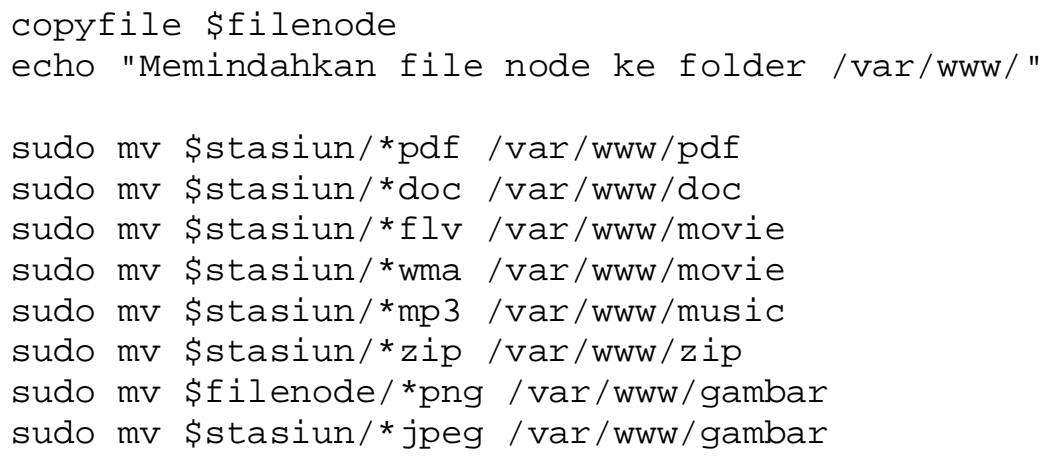




\section{Listing Program Socketserver.py}

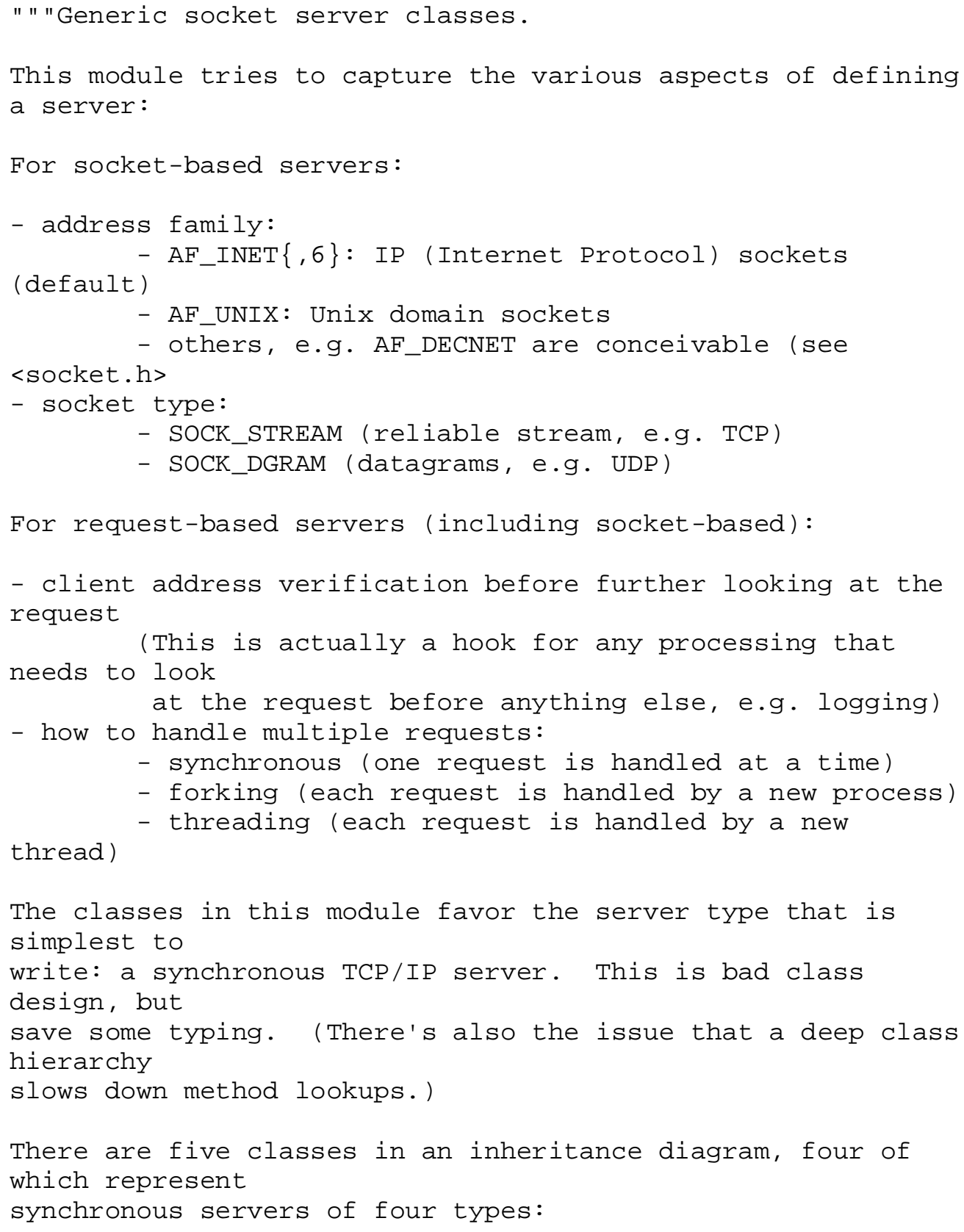




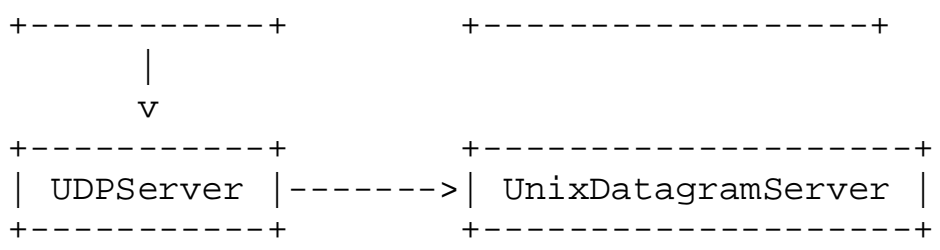

Note that UnixDatagramServer derives from UDPServer, not from UnixStreamServer -- the only difference between an IP and a Unix stream server is the address family, which is simply repeated in both unix server classes.

Forking and threading versions of each type of server can be created

using the ForkingMixIn and ThreadingMixIn mix-in classes.

For

instance, a threading UDP server class is created as

follows:

class ThreadingUDPServer(ThreadingMixIn, UDPServer):

pass

The Mix-in class must come first, since it overrides a method defined

in UDPServer! Setting the various member variables also

changes

the behavior of the underlying server mechanism.

To implement a service, you must derive a class from

BaseRequestHandler and redefine its handle() method. You can then run

various versions of the service by combining one of the server classes

with your request handler class.

The request handler class must be different for datagram or stream

services. This can be hidden by using the request handler subclasses StreamRequestHandler or DatagramRequestHandler.

Of course, you still have to use your head!

For instance, it makes no sense to use a forking server if the service

contains state in memory that can be modified by requests (since the modifications in the child process would never reach the initial state 
kept in the parent process and passed to each child). In this case, you can use a threading server, but you will probably have to use locks to avoid two requests that come in nearly simultaneous to apply conflicting changes to the server state.

On the other hand, if you are building e.g. an HTTP server, where all

data is stored externally (e.g. in the file system), a synchronous

class will essentially render the service "deaf" while one request is

being handled -- which may be for a very long time if a client is slow

to reqd all the data it has requested. Here a threading or forking

server is appropriate.

In some cases, it may be appropriate to process part of a request

synchronously, but to finish processing in a forked child depending on

the request data. This can be implemented by using a synchronous

server and doing an explicit fork in the request handler class

handle () method.

Another approach to handling multiple simultaneous requests in an

environment that supports neither threads nor fork (or where these are

too expensive or inappropriate for the service) is to

maintain an

explicit table of partially finished requests and to use select () to

decide which request to work on next (or whether to handle a new

incoming request). This is particularly important for stream services

where each client can potentially be connected for a long

time (if

threads or subprocesses cannot be used).

Future work:

- Standard classes for Sun RPC (which uses either UDP or TCP)

- Standard mix-in classes to implement various authentication 
and encryption schemes

- Standard framework for select-based multiplexing

XXX Open problems:

- What to do with out-of-band data?

BaseServer:

- split generic "request" functionality out into BaseServer class.

Copyright (C) 2000 Luke Kenneth Casson Leighton

$<$ lkclesamba.org $>$

example: read entries from a SQL database (requires overriding

get_request() to return a table entry from the database). entry is processed by a RequestHandlerclass.

\section{" " "}

\# Author of the BaseServer patch: Luke Kenneth Casson Leighton

\# XXX Warning!

\# There is a test suite for this module, but it cannot be run by the

\# standard regression test.

\# To run it manually, run Lib/test/test_socketserver.py.

_version_ $=" 0.4 "$

import socket

import select

import sys

import os

try:

import threading

except ImportError:

import dummy_threading as threading

-all__ =

[ "TCPServer", "UDP Server", "ForkingUDP Server", "ForkingTCP Serve $r "$,

"ThreadingUDPServer", "ThreadingTCP Server", "BaseRequest Handle $r "$,

"StreamRequestHandler", "DatagramRequestHandler",

"ThreadingMixIn", "ForkingMixIn"]

if hasattr(socket, "AF_UNIX") :

__all_.extend ( [ UnixStreamServer", "UnixDatagramServer",

"ThreadingUnixStreamServer", 
"ThreadingUnixDatagramServer" ] )

class Baseserver:

"" "Base class for server classes.

Methods for the caller:

- _init__ (server_address, RequestHandlerClass)

- serve_forever (poll_interval=0.5)

- shutdown ()

- handle_request() \# if you do not use serve_forever()

- fileno() -> int \# for select()

Methods that may be overridden:

- server_bind ()

- server_activate()

- get_request() -> request, client_address

- handle_timeout ()

- verify_request (request, client_address)

- server_close()

- process_request (request, client_address)

- close_request (request)

- handle_error()

Methods for derived classes:

- finish_request (request, client_address)

Class variables that may be overridden by derived classes or

instances:

- timeout

- address_family

- socket_type

- allow_reuse_address

Instance variables:

- RequestHandlerClass

- socket

" " "

timeout $=$ None

def _init_(self, server_address, RequestHandlerclass): " "Constructor. May be extended, do not

override. " " " 


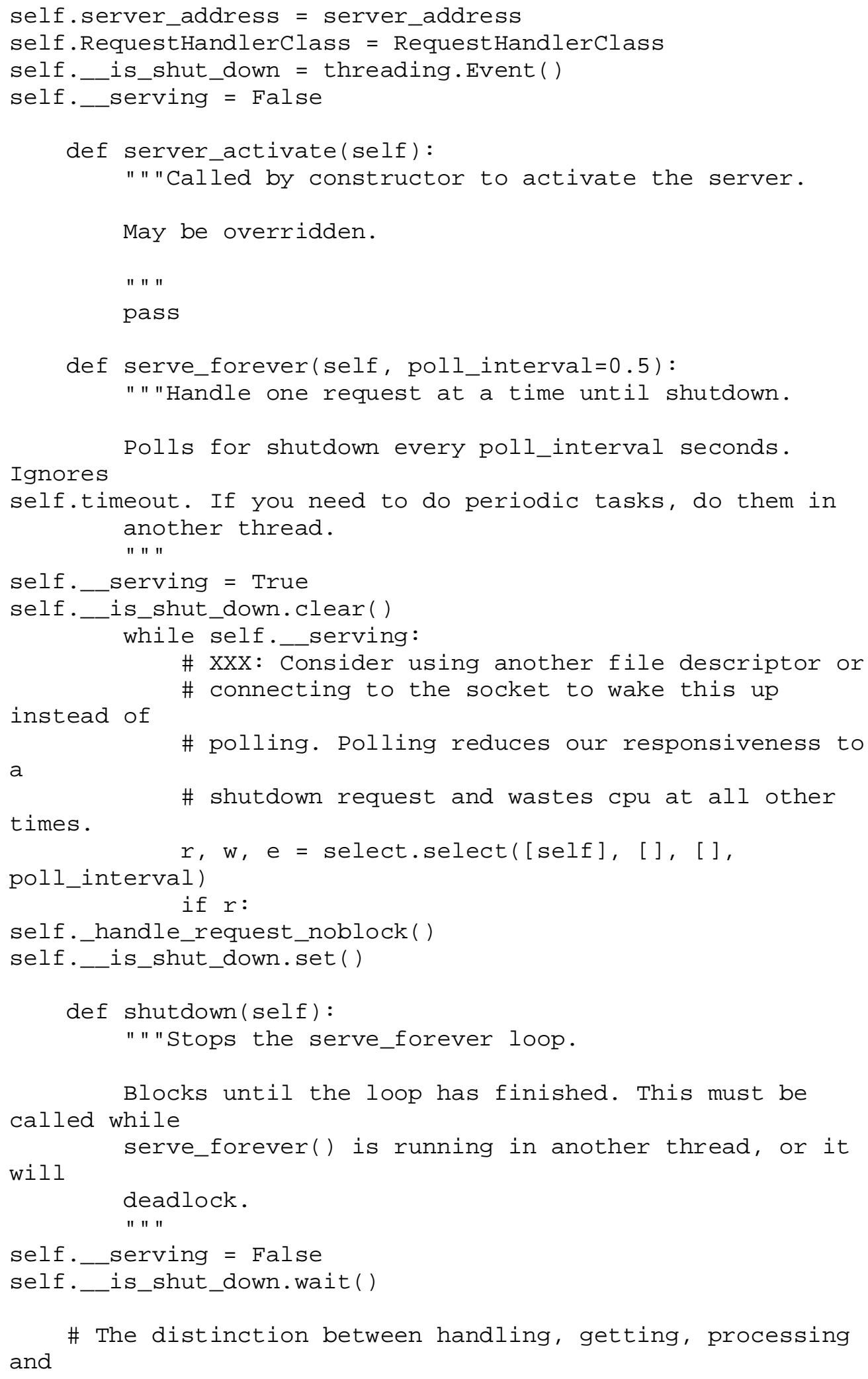




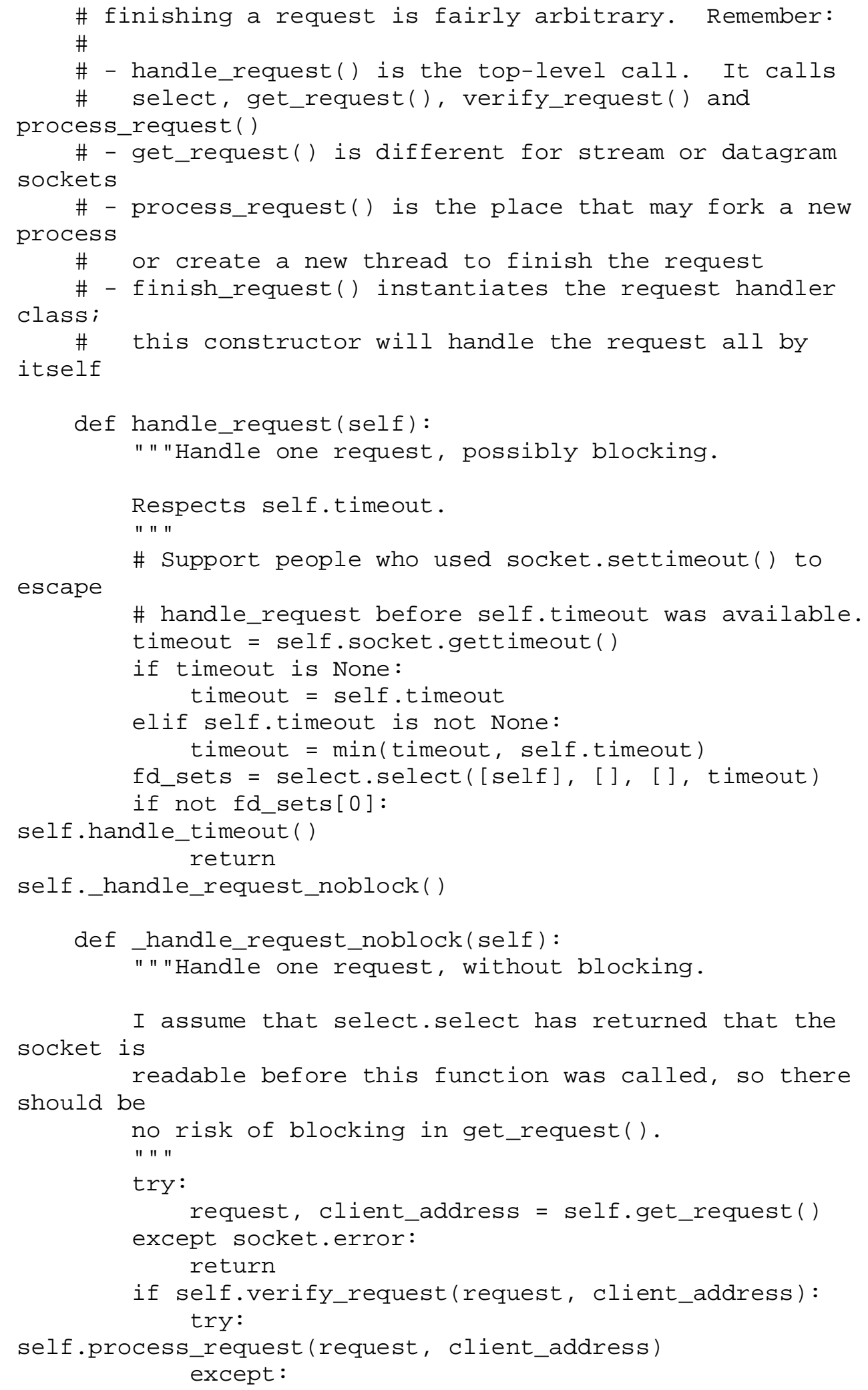




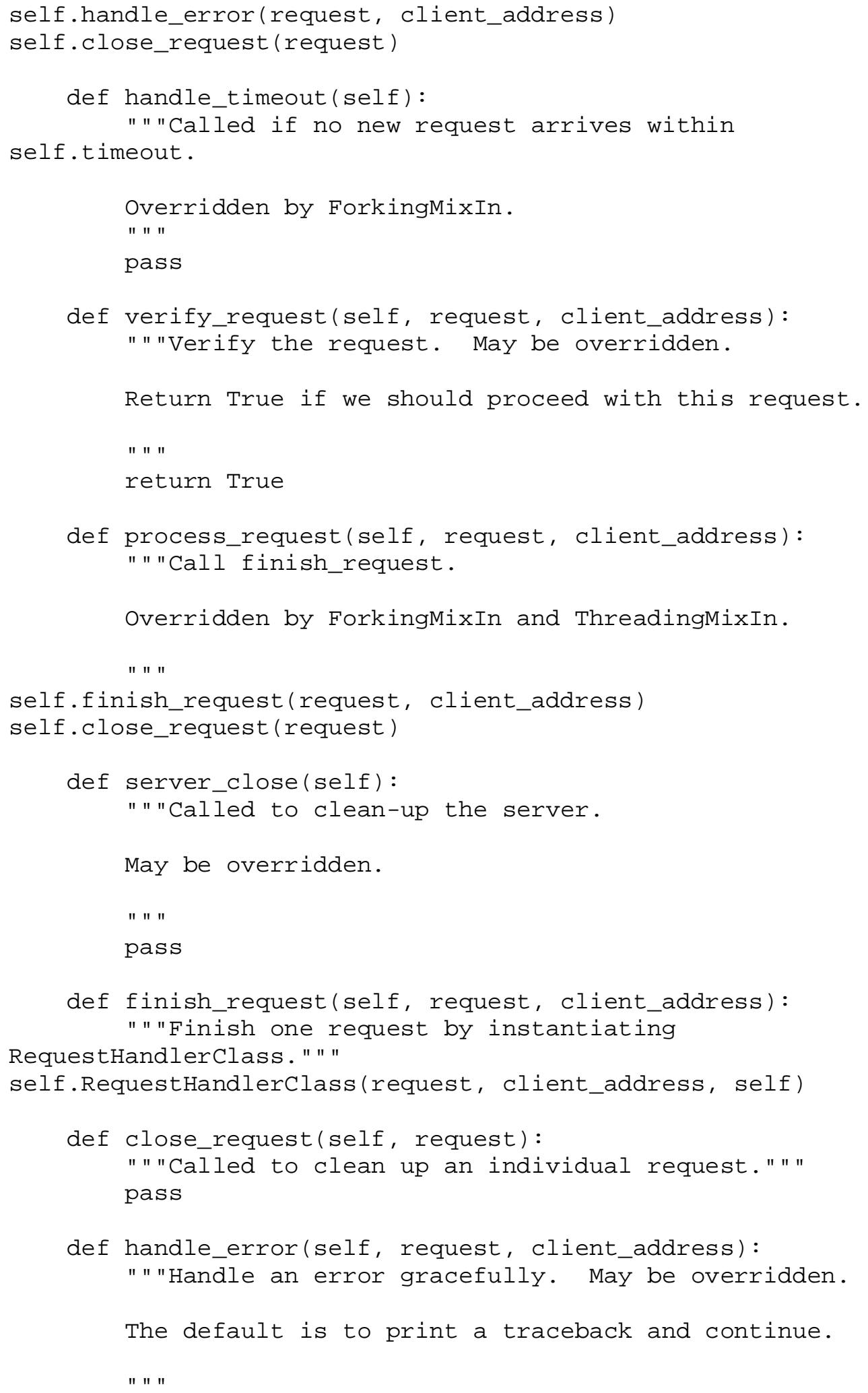




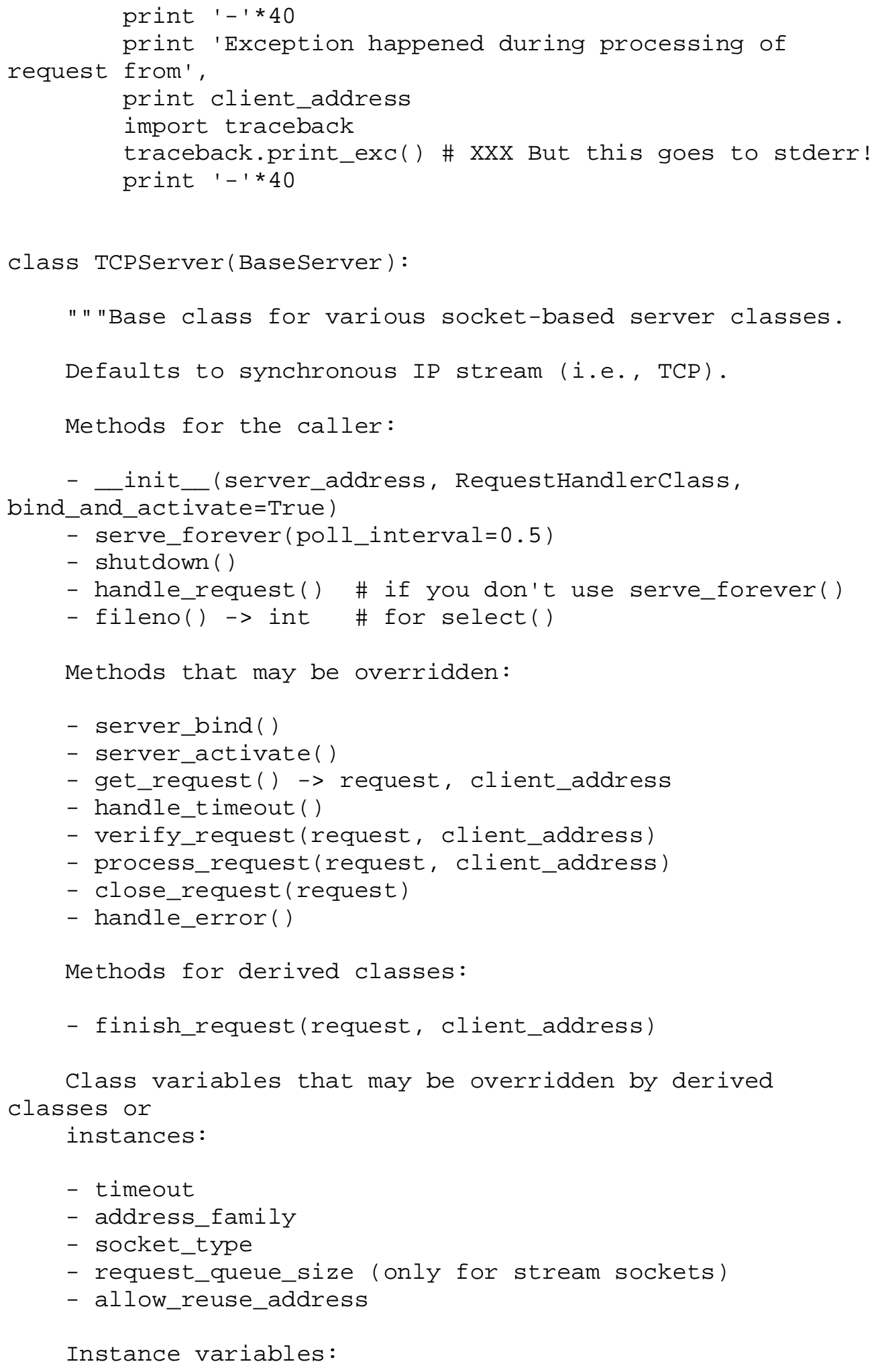




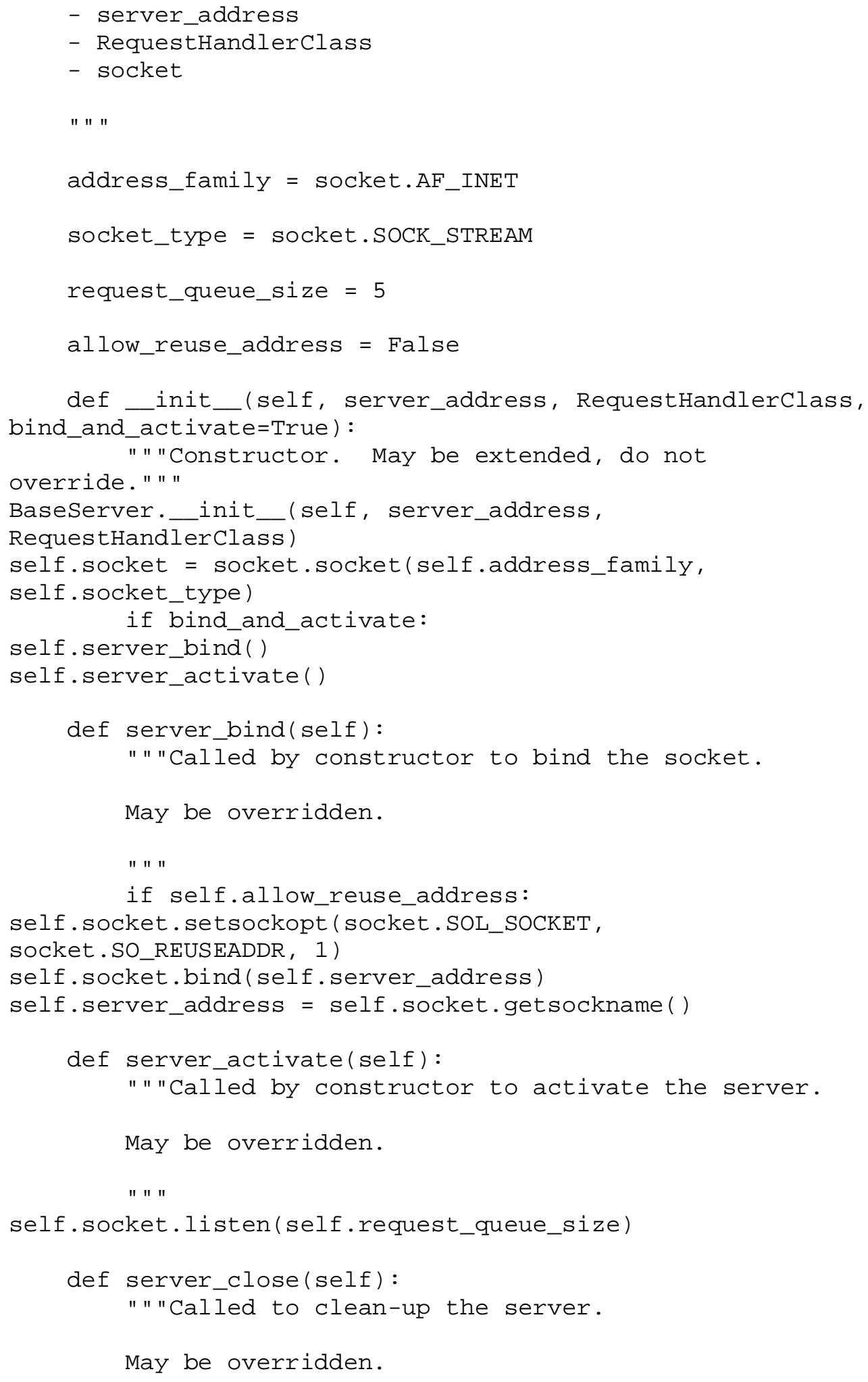




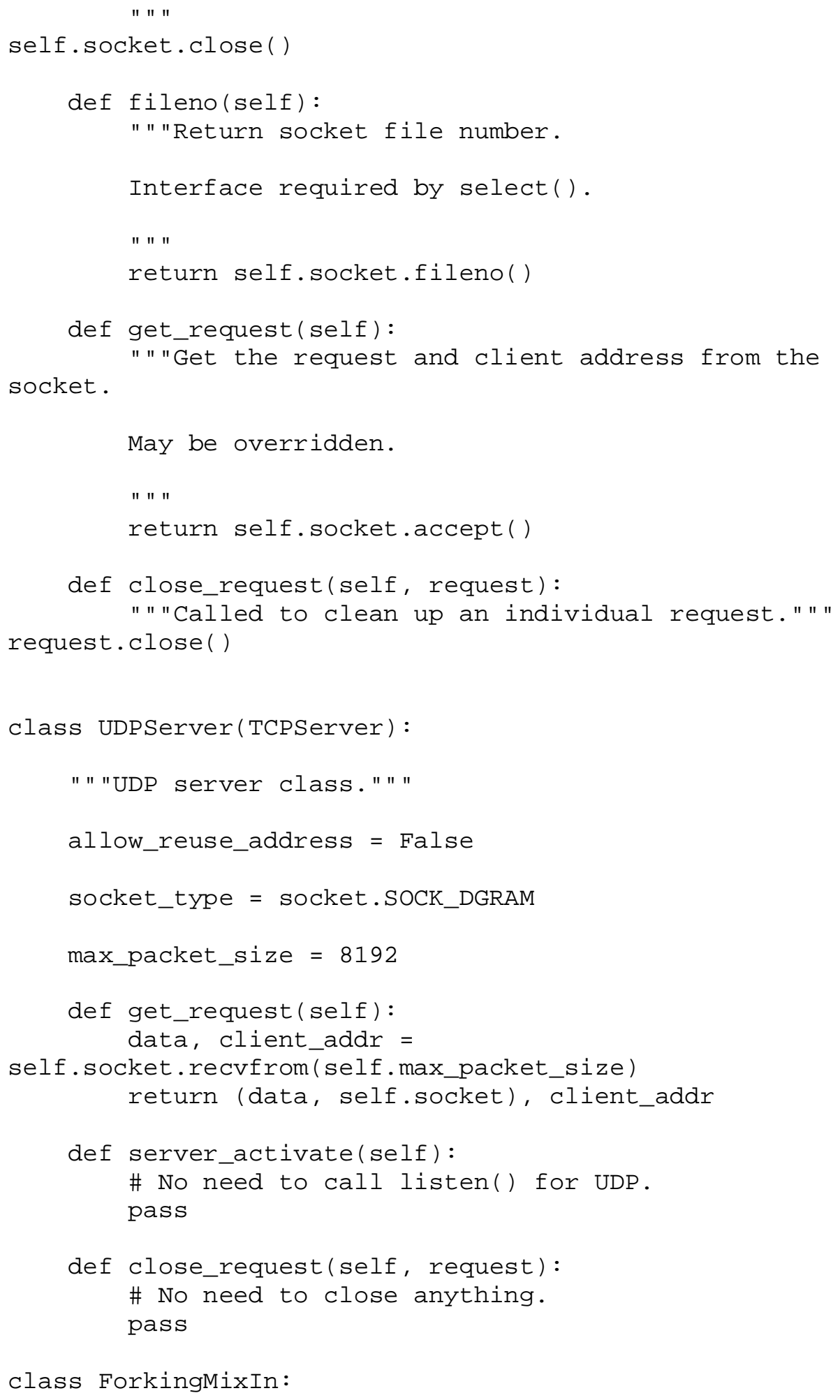




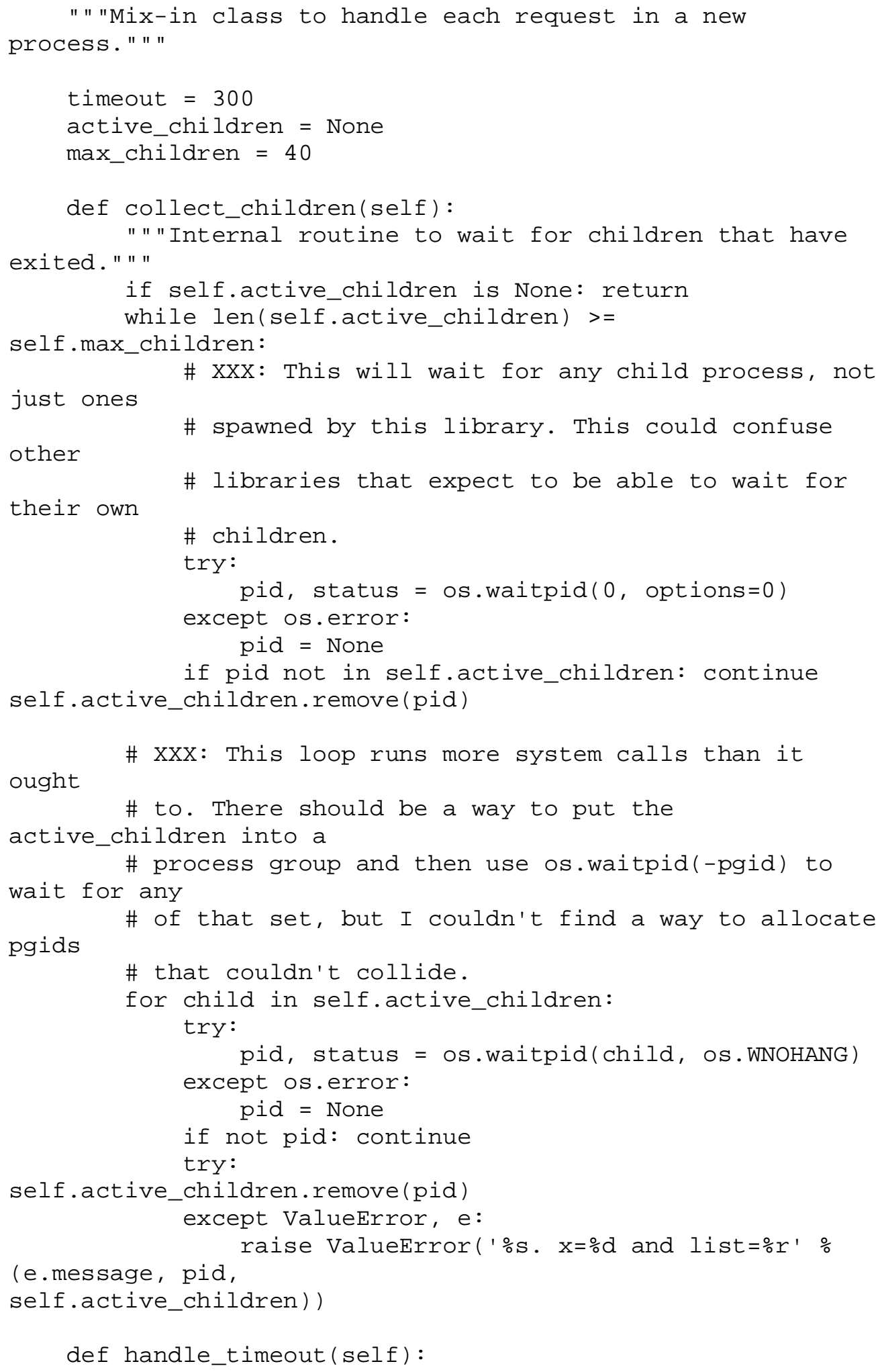




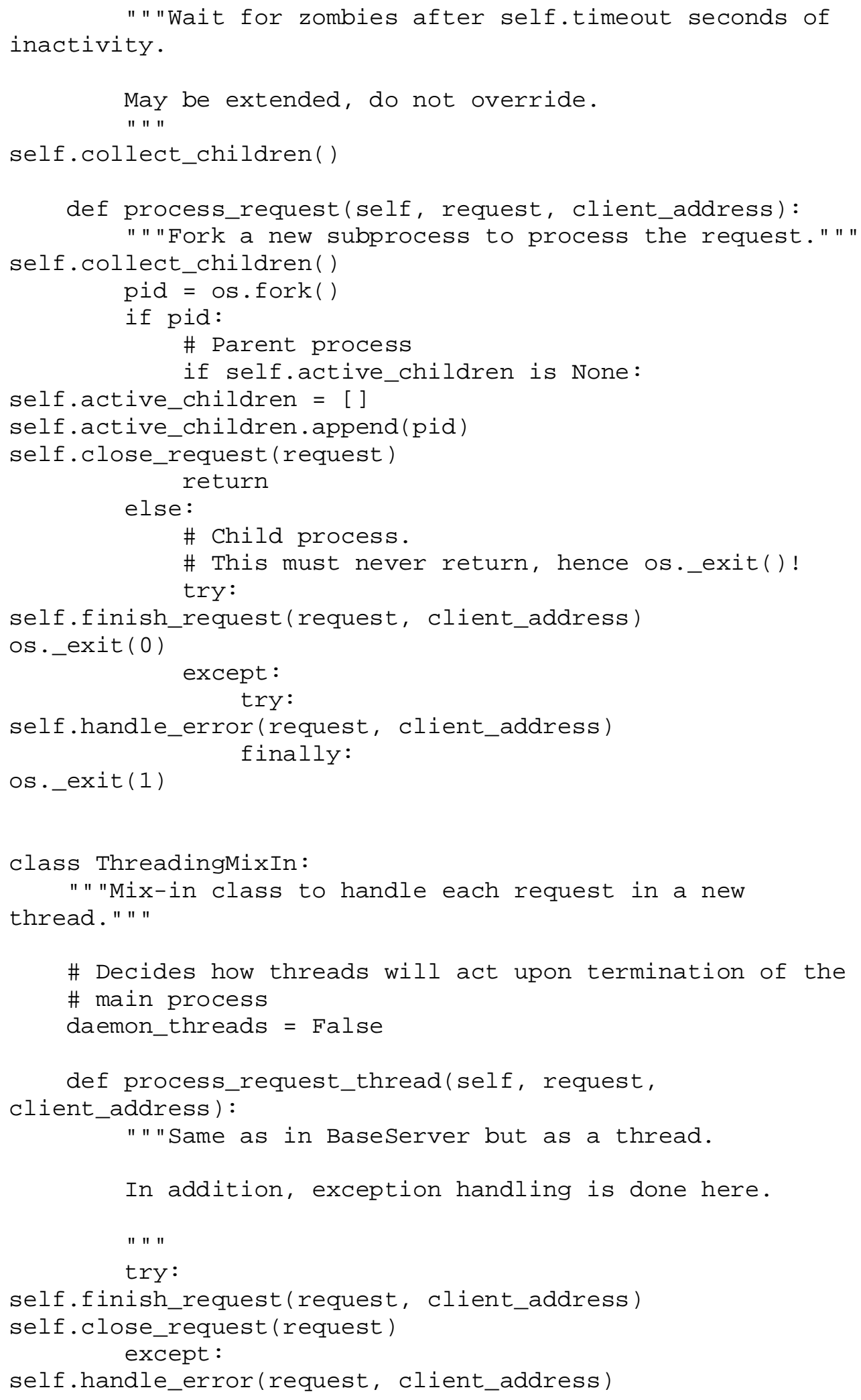




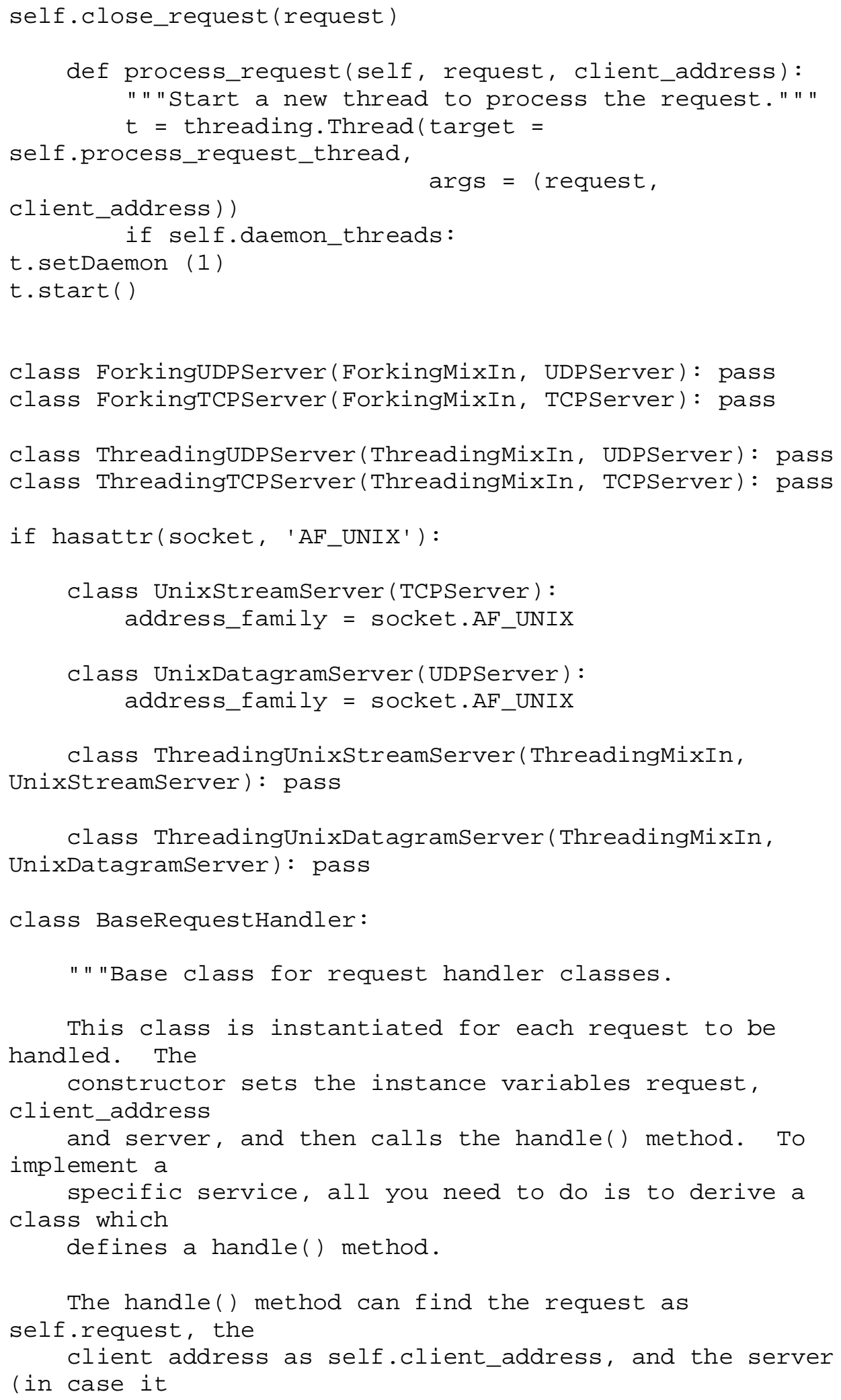




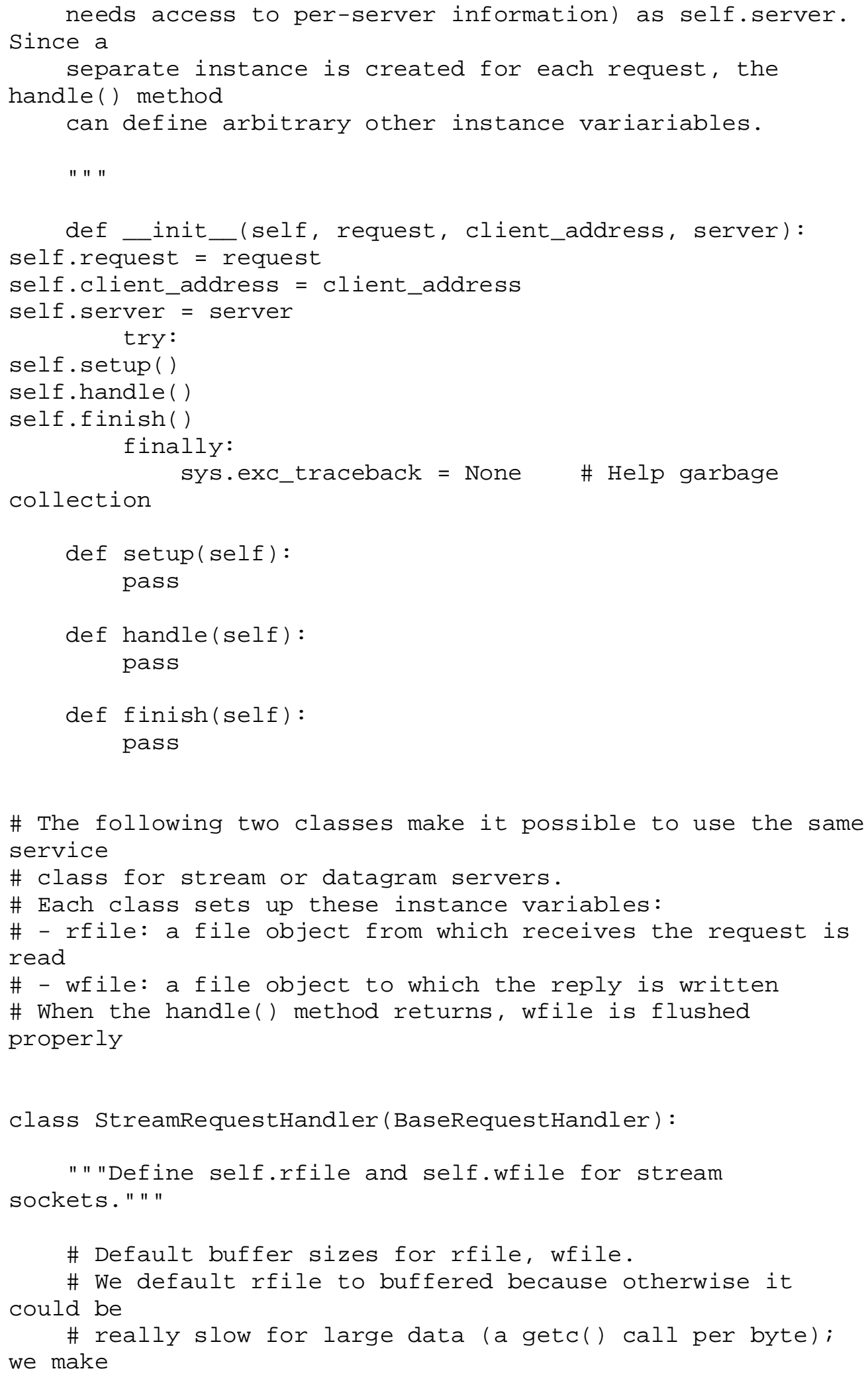




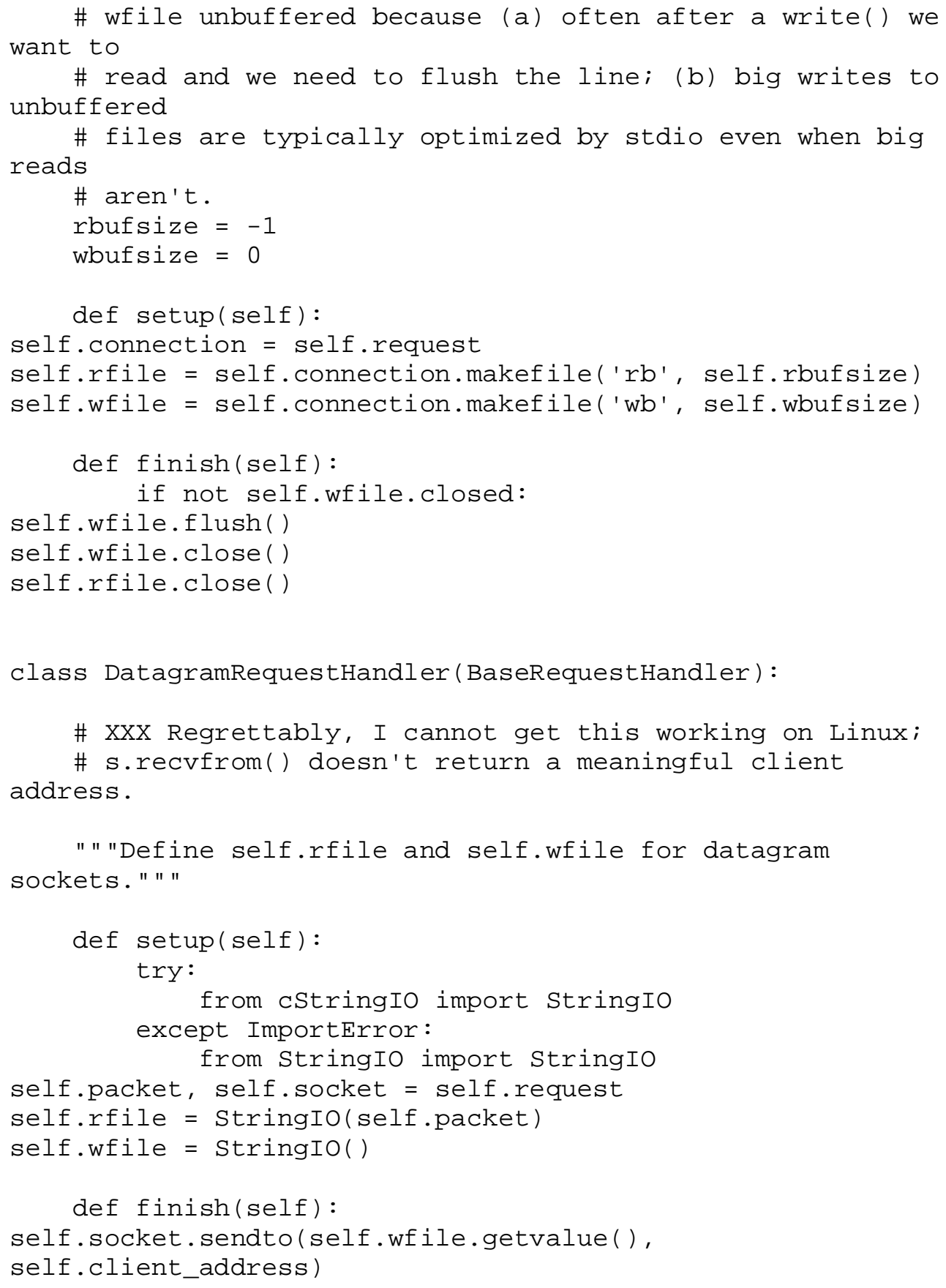




\section{LAMPIRAN C}

FGD Hasil Penelitian 

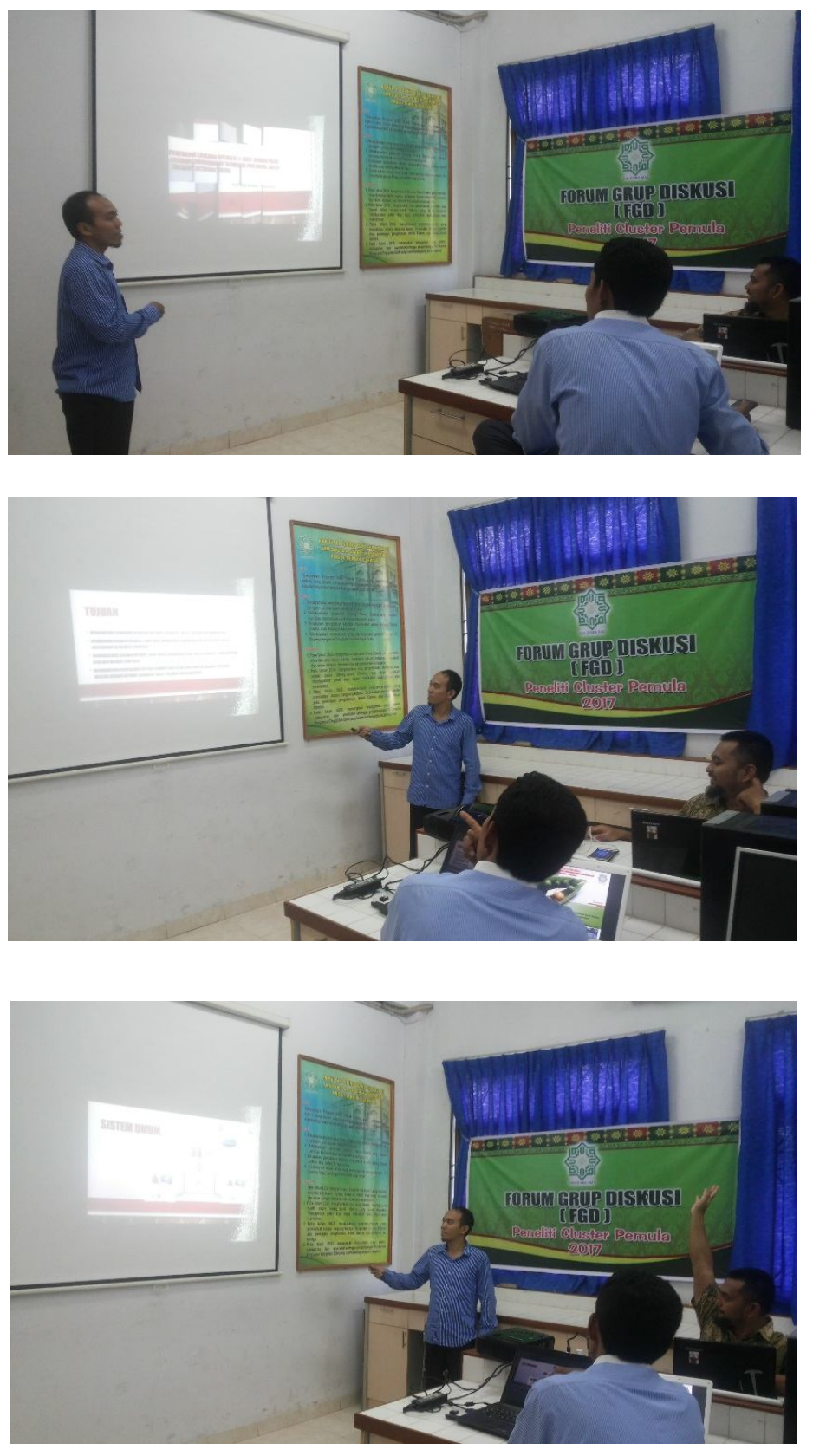